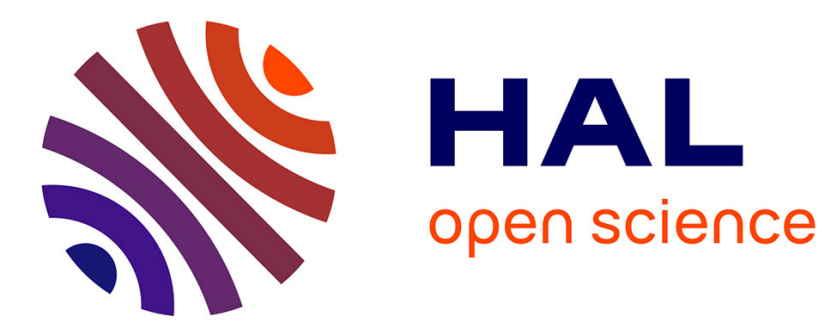

\title{
Verb Second and the Left Edge Filling Trigger \\ Mélanie Jouitteau
}

\section{To cite this version:}

Mélanie Jouitteau. Verb Second and the Left Edge Filling Trigger. Rebecca Woods \& Sam Wolfe. Rethinking V2, Oxford University Press, pp.455-481, 2020, 9780198844303. hal-02023271

\section{HAL Id: hal-02023271 https://hal.science/hal-02023271}

Submitted on 18 Feb 2019

HAL is a multi-disciplinary open access archive for the deposit and dissemination of scientific research documents, whether they are published or not. The documents may come from teaching and research institutions in France or abroad, or from public or private research centers.

$$
\text { Copyright }
$$

L'archive ouverte pluridisciplinaire HAL, est destinée au dépôt et à la diffusion de documents scientifiques de niveau recherche, publiés ou non, émanant des établissements d'enseignement et de recherche français ou étrangers, des laboratoires publics ou privés. 


\title{
Left Edge Filling Trigger \\ $\mathrm{V} 2$ as obligatory exponence at the sentence level and typological implications Mélanie Jouitteau, CNRS, IKER, UMR 5478
}

\begin{abstract}
Final version to be published in Rethinking V2, Sam Wolfe \& Rebecca Woods (eds.), Oxford, Oxford University Press.
\end{abstract}

This paper is an inquiry about the subcomponent of the Extended Projection Principle (EPP) that is relevant for second position phenomena: the Left Edge Filling Trigger (LEFT). LEFT basically amounts to a classical morphological obligatory exponence effect, except it is instantiated at the sentence level. It crosslinguistically operates in a postsyntactic realizational morphological module. I show that LEFT is an active rule of Universal Grammar, providing empirical arguments from Breton, a Celtic VSO language showing an extra conspicuous V2 requirement. I propose a radical reanalysis of language typology of word order. Classical V2 languages are conspicuously V2. SVO is a subtype. So-called V1 languages are either predicate fronting languages (Tense second), or inconspicuously V2. I discuss a crosslinguistic typology of LEFT effects, with great attention to inconspicuous satisfiers, among them null expletives for which I present evidence. I argue accordingly for a drastic extension of the typology of expletives.

This paper proposes a new take on $\mathrm{V} 2$ by bringing attention to the most inconspicuous elements that occupy the initial position before the inflected verb. It is first argued that the V2 requirement is in itself post-syntactic. A close look at possible word orders in Breton (Celtic) shows that when syntax and information structure conspire for Tense-first orders, the language makes use of last-resort non-syntactic operations that violate the Head Movement Constraint and/or the syntactic ban on excorporation. Syntactic accounts of V2 fall short in accounting for these syntactic violations that happen only in all-focused or out-of-the-blue contexts, as well as their ultralocality as in Stylistic fronting. I argue that V2 fundamentally derives from a morphological obligatory exponence effect that we observe at the sentence level (Left Edge Filling Trigger, LEFT). This proposal has far reaching typological consequences. Conspicuous LEFT effects can be seen in classical V2 languages like Germanic languages or Old Romance languages, but also Japanese and Korean scrambling paradigms, or even verb-doubling paradigms in languages as diverse as Basque or Gungbe. Finally, a close scrutiny at inconspicuous LEFT effects (dropped elements, null expletives, C heads...) allows for a reclassification of classical Verb-first languages like Arabic or Irish into verb-second languages, which drastically extends the typology of V2. 
The paper is organized as follows. Section one provides a historical perspective on studies into the nature of the EPP with respect to verb-second phenomenon. Section two isolates the Left Edge Filling Trigger and illustrates with the Breton merged expletive bez'. Breton has a transitive expletive that does not impose restrictions on the postverbal subject, which shows that LEFT is neither vacuous nor redundant with Case assignment effects or relations of phifeatures. Section three presents arguments that Breton LEFT effects are post-syntactic. I propose they are realized in a morphological module before Vocabulary Insertion. I show that LEFT effects are ultra-local and syntactically ill-behaved. In Breton the obligatory exponent satisfying LEFT originates from the linearly closest post-head element (Stylistic Fronting, Long Head Movement), or from the head itself (excorporation followed by a $d o$-support insertion, or even idiosyncratically leading to doubling). Section four reviews some paradigms that fall under the empirical domain of LEFT effects: V2 word order of wide focus sentences in V2 languages, Stylistic fronting, or short Scrambling in Korean and Japanese, verb-doubling in Western Basque or Gungbe. In section 5, I explore crosslinguistic paradigms with inconspicuous LEFT satisfiers. I address the question of null expletives. Section six summarizes how LEFT effects design a new typology of languages.

\section{Historical perspective on studies about the EPP}

The Extended Projection Principle (EPP) appeared in Generative Grammar in Chomsky (1982:10), mainly to contrast sentences and nominal structures: the former need a subject whereas the latter do not. Chomsky's (1986:46) implementation of the EPP stresses the notion of subjecthood: a subject must be present in Surface Structure. The EPP therefore has accounted for the insertion of expletives since the 80s: Manon seems _to be laughing, but (It)* seems that Manon is laughing. Subjecthood-centric versions of the EPP were challenged by potential cases of subjectless sentences (see Babby 1991 for Russian, McCloskey 1996 for Irish), but this 'traditional EPP' is still widespread three decades later and the notion of subjecthood and the SpecIP position are still considered as classically pertaining to the EPP. During the next decade, the EPP has been used more and more, but at the same time it has been transformed so as to account for a larger set of empirical facts. First we saw a multiplication of the syntactic locations where EPP was postulated, and second we saw a radical extension of the typology of elements that could satisfy the EPP.

The multiplication of EPP sites in the structure started in the late 90s, when Case or Agreement relations could be made in syntax at a distance. Overt movement became entirely 
redundant, and its motivation was endorsed by EPP features that can be freely postulated (on nominal structures, or on $v$ P for object-shift, cf. Lasnik 1995, Chomsky 2000:102, 2001:10). This line of analysis is referred to as Generalized EPP. Its drastic extension of the location of EPP effects has triggered in the field a productive counter-wave of reductionist analyses, whose aim was to advocate for a complete elimination of the EPP as a Principle, as a Parameter or as a feature (Epstein and Seely 1999, 2006, Martin 1999, Grohmann, Drury and Castillo 2000, Boeckx 2000, Bošković 2002, 2007, Cable 2011). These reductionist analyses typically ignore the second direction of extension of the EPP paradigms, the one that extends the typology of elements that can satisfy the EPP. This second tradition of analysis has concentrated on the idea that something has to precede the inflected verb (or AGR features or tense morphology), whatever the syntactic location of this element at the end of the derivation (final EPP Bošković 2002, left edge lexicalization strategy or Filled Left Edge Effect, Sigurosson 2008, 2010). In Chomsky (1995:235,287), the EPP is implemented by means of an N/D feature, weak or strong, that must be checked. The typology of EPP-derived structures thus includes all DP-V orders: impersonal adversatives in Russian (Lavine 1998, Lavine and Freidin 2001, Bailyn 2004), quirky subjects (Ura 2000, Boeckx 2000:appendix1), dative experiencers (Maling and Zaenen 1990 and Sigurosson 2002 for Icelandic, Avrutin \& Babyonyshev 1997 for Russian), OVS orders (Bailyn 2003, 2004 for Russian, Kilega and Kirundi), etc. The drastic extension of the typology of EPP satisfiers continues with English locative inversion and subject inversion structures. The pre-Tense element, adverb or there expletive is postulated to have a nominal dimension under the form of an uninterpretable D feature (Beletti 1988, Lasnik 1999). Any element for which an interpretable nominal feature can be postulated rejoins the set of possible EPP satisfiers (for example agreement, see Alexiadou and Anagnostopoulou 1998, Kato 1999). ${ }^{1}$ A first line of research has restated the EPP in terms of obligatory projection of a specifier (Lasnik 2001, Lavine and Freidin 2001, Bailyn 2003, 2004), or binding requirement of Tense (Sigurosson 1997, Roberts \& Roussou 2002). Typically, this tradition of analysis explores locative inversion, or pre-Tense possessive PPs with A properties. The variety of pre-Tense elements naturally places V2 languages as an empirical domain derivable by EPP effects (Holmberg 2000, 2005, Grohmann, Drury and Castillo 2000, Kim 2003, Bury 2003, Rezac 2004a, Bailyn 2004, Jouitteau 2005, 2007, Landau 2007 among others...). Finally, other types of EPP satisfiers are

\footnotetext{
${ }^{1}$ Despite crosslinguistic EPP effects being obviously blind to clitics.
} 
also considered, in particular C heads, which opens the EPP derived paradigms to V2 languages with alternative C-VSO orders like Breton or middle Welsh (Bury 2002, 2003, 2005, Jouitteau 2004, 2005b:407 and chapter 6, 2005c, 2007).

In the next section, I go back to the unavoidable basics: expletive insertion has to be accounted for. I will show how Breton provides solid empirical evidence for a Left Edge Filling Trigger (LEFT) entirely independent of either the notion of subject, the specific SpecIP site, subject Agreement or Case.

\section{What Breton expletive insertion shows}

Breton is a Celtic VSO language that requires the presence of a pre-Tense element, be it a head or an XP. This type of word order is called Linear V2 in Borsley and Kathol (2000), or $X(P)$-VSO language in Jouitteau (2005). The structure is as in (1). The inflected verb is located in Fin, the lower head of an articulated CP domain (Jouitteau 2005). The subject is plausibly lower than SpecIP (Roberts 2005, Jouitteau 2005). A merged expletive can appear in polarity focus and in wide focus sentences.

$$
\text { Expletive Fin-V [IP ... }
$$

The morphology of the Breton expletive (2) is neither pronominal like French il or English it, nor adverbial like English there. Instead, its phonological realization corresponds to a shortening of bezañ, the infinitival form of the verb 'to be'. This remains true across dialectal variations, where the infinitive 'to be' and the pre-Tense expletive are realized the same (bit in the Poher dialect, bout in Gwened dialects, bez in Standard Breton).
(2)a. bi(t) so bara.
a'. bez' zo bara.
to-be (Fin) is bread
to-be (Fin) is bread
'There is bread.'
'There is bread.'
b. bi(t) ë ra glav
to-be Fin does rain.
b'. bez' e ra glav
to-be Fin does rain.
'It rains.' Poher dialect, Trevidig (1987)
'It rains.'

Standard Breton

The Fin head can be phonetically realized in Breton, and agrees in category with its preceding element (nominal $>a+$ lenition, non-nominal $>e+$ mixed mutations, Rezac 2004a). It is a 
noteworthy property of the pre-Tense expletive in (2) that it is compatible with both realizations of the Fin head. Expletive insertion has a null semantic impact and never impacts the truth conditions of the sentence. Its effect, if any, is pragmatic. The equivalent of a verum focus effect on the verb is reported by Le Gléau (1973:45), Trépos (2001:440), Gros (1984:110), Favereau (1997:§443) and Chalm (2008:212), Bottineau (2009:4). ${ }^{2}$ Crucially, however, association of verum focus with bez' is possible but not obligatory. Contextually enforced verum focus in (3b) is pragmatically odd in (3a).

(3) a. Bez' omp digemeret en eur zal vraz spontuz. Miossec $(1984: 7)$

EXPL Fin.are.1PL welcome in a room big terrible

'We are welcomed in a terribly big room.'

b. Bez' he-deus da vihanna, tri-ugent metr hed ha tregont metr lehed. EXPL Fin.3SGF-has at least three-twenty meter long and thirty meter large '(Indeed) It is at least sixty meter long and thirty meter large.'

One could be tempted to think of bez as a C Focus head transmitting Focus to either the polarity head or to the entire sentence. This is however not plausible, because focus sentence particles are semantically compatible with negation (for example in Nupe, see Kandybowicz 2008:37), but co-occurrence with negation is not an option in Breton. In the contrary, bez is in mutual exclusive distribution with any other pre-Tense element: negation, past participle, $\mathrm{C}$ matrix particle, subject or object. The distribution of bez' reveals a pure last resort operation repairing a ban on Tense-first: bez is never found in a post-Tense position, and any other preTense element makes it illicit. In embedded domains, bez is only licit in structures that independently allow for embedded V2 orders, typically if-sentences (4).

(4) Lavar din ha bez' e teui.

tell to.1SG if EXPL Fin come.FUT.3SG

'Tell me if he is going to come.'

Kerne, Trépos (2001:322)

In contrast with the English 'there' type of expletive, $b e z$ ' triggers no definiteness effect on

\footnotetext{
${ }^{2}$ Bottineau (2009:4) states that the most common effect 'is reinforcement of the assertive force, centered on the speaker and potentially in conflict with the addressee, with pragmatic values close to those of the question and the so-called emphatic do-support of present-day English'. [my translation].
} 
the canonically postverbal Breton subject, is not restricted to unaccusative constructions and shows no restriction to $3 \mathrm{SG}$ (Jouitteau 2007). Bez never appears in infinitives, even those allowing for an overt subject (prepositional infinitives, narrative infinitives, cf. Rezac 2011). Lexical availability of bez varies across Breton varieties depending on the verb that follows. In Eastern dialects (Treger, Gwenedeg), bez'/bout appears only before inflected verbs that contain the root of the verb 'to be'. The vannetais dialect of Herrieu (1994) also has occurrences before kaout, 'to have', derived from 'to be'. ${ }^{3}$ Gros $(1984: 110)$ states for Treger that bez' appears before bezañ, 'to be', kaout, 'to have' and gouzout, 'to know' (see also Hewitt 1988). In contrast, the expletive is found before any lexical verb in Western varieties like Kerne, Leon or Standard Breton. ${ }^{4}$
Bez' e prenis eul levr d' am breur deh.
expl Fin bought.1SG a book to my brother yesterday
'I have bought my brother a book yesterday.' Leon/Standard Breton, Fave (1998:51)

The Breton bez expletive of Kerne, Leon and Standard Breton is thus a pre-Tense, nonpronominal free expletive. ${ }^{5}$ The very existence of such expletives in human language has deep theoretical implications, because it stands in opposition to the versions of the EPP that make reference to the notion of subjecthood (Chomsky 1982, 1986), as well as to the different attempts to reduce expletive insertion to semantics or to Case. The Inverse Case Filter (ICF, Bošković 2002, see also Bošković 1997, 2007, Epstein and Seely 1999, Ormazabal 2002) is a requirement that traditional Case assigners have to assign their Case, predicting expletive insertions where Case is canonically assigned (cf. English there). The Inverse Case Filter is typically used to account for EPP effects in SVO paradigms. In Breton, however, LEFT and ICF make predictions for different location sites, because the subject is Case licensed after Tense (6). ICF, if any, is active on the right of the inflected head, whereas the expletive shows up on its left. As schematized in (7), the argument holds for VSO languages such as Arabic or Celtic, and for Germanic V2 languages such as Dutch, Frisian, German or Icelandic that show

\footnotetext{
3 In Eastern varieties, bez'/bout-V orders could derive entirely from verb-doubling, a process that is independently available in the language (Jouitteau 2011 and section 6 below).

${ }^{4}$ For examples before lexical verbs in Kerne, see Trépos (2001:440), Chalm (2008:212), and for Leon and standard, see Leclerc (1986:63, fn2), Abeozen (1991:45), Fave (5) and Le Gléau (1973:45). See also de Rostrenen (1795:179) for the complete paradigm of the verb karout, 'to love', preceded by 'bez.

${ }^{5}$ Breton is not isolated in showing Transitive Expletive constructions that do not impose restrictions on the postverbal subject. Such TECs exist in Finnish (Holmberg and Nikanne 2002) and Czech (Rezac 2004b:238)
} 
Transitive Expletive Constructions (TECs). It also holds in V2 languages that lack TECs and obtain V2 orders by pre-Tense movement, such as the Mainland Scandinavian languages Norwegian, Danish and Swedish.

(6)

$\begin{array}{ccccc} & \text { LEFT ICF } & \text { IC } & \text { Breton, Treger dialect (Gros 1984:110) } \\ B e z & \text { 'nevo } & \text { hennez } & \text { traou. } \\ \text { EXPL } & \text { Fin.[will.have] } & \text { he } & \text { things }\end{array}$

'He will have goods.'

DEFT / ICF $\curvearrowright$ Celtic, Arabic, Germanic

(7) VSO/V2 type: $[$ FinP $\longrightarrow[$ Fin $\mathrm{V} \quad \mathrm{S}$

ICF could conceivably be responsible for postverbal expletive insertions like in (8) or (9) in Arabic or Swedish. However, in Swedish, if the pre-Tense adverb in (9) is dropped, the expletive appears on the left (10), a fact that ICF in (9) could not account for (in contrast with LEFT). ${ }^{6}$

$\begin{array}{lllll}\text { Kaan } & \text { famma } & \text { barsha } & \text { naas } & \text { huuni. } \\ \text { was. SG } & \text { there } & \text { many } & \text { people } & \text { here }\end{array}$

'There were many people here.'

Tunisian Arabic, Chekili (2004)

(9) Idag har det kommit många lingvister hit . today have it come many linguists here

'There have arrived many linguists here today.'

Swedish, Platzack (1998:56)

(10) Det har _ kommit många lingvister hit.

It have come many linguists here

'There have arrived many linguists here.'

Swedish, Platzack (1998:56)

Under the proposal developed here, the so-called EPP effects in English result from the interaction of two independent rules, namely ICF and LEFT. It is difficult and arguably

\footnotetext{
${ }^{6}$ There is a debate as to whether expletives can move to SpecIP. Moro (1997), Hoekstra and Mulder (1990), Sabel (2000) among others suggest that expletives are generated lower than IP and then moved to SpecIP. Bošković rejects this idea and shows that in infinitives, expletives can only be generated in situ. The hypothesis of expletive movement by LEFT effects is not affected by these arguments.
} 
inadequate to study these two rules exclusively in SVO languages like English or French, because both rules happen to have a common target site location in these languages.

A third theoretical implication of the Breton bez expletive paradigm concerns the "vacuity argument' raised against the EPP in the literature. This tradition of analysis has demonstrated that in pro-drop languages, a hypothetical pre-Tense null expletive fails to show any association with a post-Tense subject (see Fassi-Fehri 1993:38-42 for Arabic, McCloskey 1996 for Irish, Alexiadou and Anagnostopoulou 1998 for Greek, and Rossello 2002 for Spanish and Catalan). This line of reasoning contrasts the hypothetical free null expletive with realized expletives like there or the Transitive Expletive Constructions in Mainland Scandinavian (Vangsnes 2002), claiming that postulating a null expletive would amount to positing a free pre-Tense expletive without any overt equivalent. The Breton data shows overt evidence for an overt free pre-Tense expletive: it is thus not the case that LEFT satisfaction in pro-drop languages would involve an ad-hoc exotic expletive (at least, not more exotic than the overt Breton one).

I conclude here that there does exist in human languages a trigger for the insertion of a free pre-Tense expletive. The Breton data shows that the free expletive cannot be reduced to a semantic or pragmatic effect, that it is independent of the notion of subjecthood, as well as that of nominal features.

\section{LEFT as obligatory exponence at the sentence level}

In this section, I will present the Breton paradigms that show signs of post-syntactic behavior in order to back the claim that LEFT amounts to obligatory exponence that applies at the sentence level in a post-syntactic morphological module. As a morphological trigger, LEFT allows for idiosyncratic exceptions. Its effects should be ultra-local, and show a linear dimension that captures equally head-movement and XP-movement. They should show themselves some signs of idiosyncrasy.

\subsection{Morphological second position effects}

Crosslinguistically, LEFT effects are known to be independently active in morphology: EPP effects indeed have been reported at the word-internal level. Obligatory exponence derives absolutive displacement in the inflectional morphology of Yimas (Papua New Guinea; see Foley 1991 and Phillips 1994), and ergative displacement and ergative doubling in the 
inflectional morphology of Basque (see Rezac 2004b). Another second position phenomenon at the level of the sentence is also illustrated by the paradigms of clitic second languages, for which post-syntactic rules are commonly postulated (see Anderson 2005 for an overview and a morphological OT proposal for both clitic second and verb-second, as well as Bošković, this volume).

In all the preceding Breton sentences above, absence of the pre-Tense expletive would automatically trigger ultra-local fronting of an element as a last resort strategy avoiding Tense-first (in Breton, this phenomenon is known as Long Head Movement, or Stylistic Fronting in Borsley, Rivero and Stephens 1996, Rivero 1999). The interesting fact here is that LEFT short-movements seem free from syntactic rules, pointing toward a post-syntactic phenomenon. This last-resort movement operation already analyzed as pertaining to a postsyntactic/pre-PF component (Rivero 1999 for Breton, Burton Roberts \& Poole 2006 for Icelandic). The concurrent syntactic accounts can be designed so as to manipulate heads as well as bigger constituents. In the next section, I will show two other sorts of last-resort strategies for the avoidance of tense-first: analytic tenses and verb-doubling. I argue that these paradigms provide additional arguments for the proposal that LEFT is post-syntactic.

\subsection{Syntactically ill-behaved ultra-short-movement paradigms}

The Head Movement Constraint (Travis 1984) fails to apply in (11), where the past-participle head has crossed the Fin head and the head of the auxiliary. The syntactic ban on excorporation (Roberts 1991) fails to apply in (12), where the lexical verb is excorporated out of the tensed complex and appears initial with an infinitive default morphology, while do insertion provides morphological support for Tense and the features of agreement (Jouitteau 2011). A particular case of excorporation arises when verbs excorporate without calling for $d o$ support. The lower inflected copy is thus pronounced, leading to verb-doubling structures as in (13), irrespective of the theta-criterion. Verb-doubling is also highly idiosyncratic, another hallmark of a morphological operation (Jouitteau 2011). ${ }^{7}$

(11) Prenet em eus _ ul levr evit ma breur deh. bought Fin.have.1SG a book for my brother yesterday 
'I have bought my brother a book yesterday.'

Stylistic Fronting

(12) Prenañ a ris ul levr d' am breur deh.

to.buy Fin did.1SG a book to my brother yesterday

'I have bought my brother a book yesterday.'

Excorporation and 'do' support

(13) Goud a ouien eur mare zo lar e oa teo ar vamm!

to.know Fin knew.1SG a time is C Fin was fat the mother

Verb Doubling

'I knew since a long time that the mother was fat!'

Uhelgoat, Skragn (2002:89)

Such syntactic violations are never licit elsewhere in the language. They appear exclusively in the immediate position before Tense, exclusively from ultra-local sites, and exclusively as a last resort for avoiding Tense-first. Adapting Rivero (1999), I propose that LEFT satisfaction movement operates in the PF branch and that LEFT effects occur on the left of a phase being linearized. The particular identity of this phase is language dependent, it is FinP in Breton. The Breton structure showing avoidance of Tense-first is illustrated in (14), where the morphologically complex head $H 1$ is linearized on the left edge of the phase it heads. $H 1$ contains different morphemes, $M_{x}$ and $M_{y}$. Be it a head or an XP, H2 is a constituent that linearizes immediately after $H 1$. The alternative repair strategies are illustrated below. In (15), the closest linearized element $H 2$ is inverted with $H 1$. In (16), morphological material is extracted out of $\mathrm{H} 1$. The $M_{x}$ morpheme appears fronted before $\mathrm{H} 1$ where do insertion provides morphological support for $M_{y}$. In (17), the same excorporation arises, but instead of do support, morphology chooses to spell-out the lower copy of the extracted element. The empirical result is verb-doubling as in (13).

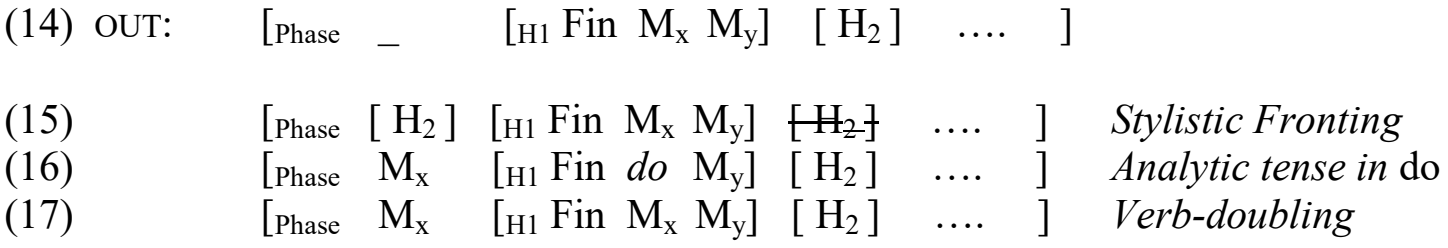

LEFT short-movement strategies do not obey syntactic constraints (Head Movement Constraint, ban on excorporation), but are far from unconstrained. No subcomponent of $H 2$ ever fronts: a fronted subject or adverb cannot be short-moved without its modifiers. Not all

\footnotetext{
${ }^{7}$ Properties of Stylistic Fronting in Breton are detailed in Jouitteau (2005:chap 5, 2007). Properties of analytic tenses in 'do' and their analysis in terms of excorporation are detailed in Jouitteau (2011). The last resort dimension of verb-fronting for V2 has been noted since Stephens (1982) and Hewitt (1988).
} 
H1 material can be excorporated. The Fin head and agreement morphemes typically cannot. If a lexical verb $M_{x}$ bears a clitic object, this clitic has to appear on $M_{x}$. Only short $\nu \mathrm{P}$ adverbs (sometimes polysyllabic) can appear on $M_{x}$ as in (18) and (19).

(18) Kompren (mat/*alies) a ran (mat/alies ) tout an traoù a larit. to.understand well/often Fin do.1SG well/often all the things Fin say.2PL 'I understand (well/often) the things you say.'

[D.L] Quimperlé

(19) [...], ha gouzout mat a ouzon e save pennadou flemmus hag entanet [...] and to.know well Fin knew.1SG Fin put.up.3SG articles biting and passionate 'And I knew well he was writing biting and passionate articles...'

Cornouaillais (Pleiben), ar Go (1950:7)

It is not the case that LEFT effects are anchored to the extreme left of a realized utterance: linearization proceeds from phase to phase, and consequently designs a 'glass ceiling' on the left-edge of the phase above, which morphemes cannot serve as exponents anymore. The Breton high left-periphery of CP hosts hanging topics and scene setting adverbs, which are persistently invisible for LEFT effects (Jouitteau 2005 for Breton, see also Wolfe, Salvesen and Haegeman,xxx Greco this volume).

(20) Pan erruo ar brini du, douget gant an avel gwalarn, tostaat a reio ar goanv. when arrive.FUT the ravens black brought by the wind northeast, approach Fin do.FUT the winter 'When the black ravens come, brought by the Northeast wind, winter will be at hand.'

Standard, Le Bozec (1933:18)

Both Breton Stylistic Fronting and analytic tenses in do or doubling bear the LEFT signature properties listed in (21). The last resort dimension of short-movement is evidenced by its mutual exclusive distribution with any other pre-Tense element. Short movement is never observed in another location than directly before the Tensed element. Consistent with the hypothesis that short movement operates during linearization in a postsyntactic module, it is characterized by its ultra-local domain of impact: the moved element is either the closest postTense element (Stylistic Fronting) or a subpart of the Tensed element itself (Analytic Tenses in $d o$, doubling). No longer movement is ever observed. Another consequence of LEFT operating in the PF branch is its invisibility at LF, as expected in a T model as in (22), where $M$ stands for a morphological component à la Embick and Noyer (2001). As predicted, the T2 
sentences in (11) and (12) are not semantically distinguishable from their counterpart with expletive insertion in (5).

(21) (i) Last resort operation

(ii) Ultralocality (very short movement)

(iii) Lack of impact at LF

(iv) Blindness to the head/XP distinction,

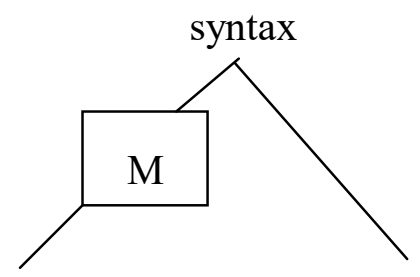

sensorimotor system interpretation system

LEFT effects are obviously blind to the X/XP distinction: a post-Tense subject is fronted in the same manner as a post-Tense lexical verbal head. Obligatory exponence at the phase level derives the possibility of Breton unmarked SV_O orders as in (23), which solves a classical mystery of Breton syntax. The inflected Breton verb stands in Fin, the position phonologically signaled by its a/e realization: the inflected verb is thus directly dominated by the A-bar field where presence of A subjects is unexpected. However, the pre-Tense subject in Breton wide focus sentences does show A properties (Stump 1984, 1989, Borsley and Stephens 1989, Rezac 2004a, Jouitteau 2005:chap2, 2007). LEFT predicts that the subject of SV_O unmarked orders will show A-properties, because for all LF interpretation is concerned, this sentence is VSO, with the subject standing in the directly post-Tense canonical A position. Even objects can be fronted by short-movement, as long as the derivation leaves them standing as the closest post-Tense element: in (24) the object is extracted out of an idiom chunk with an unmarked reading. ${ }^{8}$

Marijo a breno $\quad$ ul levr evit Azenor.
Marijo Fin bought.will a book for Azenor
'Marijo will buy a book for Azenor,

'Marijo will buy a book for Azenor.'

Standard Breton

(24) An êr

az-peus _ da houzoud ar vicher!

Object short-fronting the appearance (Fin) 2SG-has of to.know the job

'You look like you know what you're doing!'

Léon, Seite (1998:13) 


\subsection{Lack of motivation for LEFT in syntax and semantics is expected}

LEFT is the name of a theoretical trigger that remains here unmotivated in both modules of syntax and semantics. This is a desired result if, as suggested by the Breton facts, this rule is post-syntactic in nature. Different lines of hypothesis have proposed to derive V2 from a higher requirement, like a need for Tense to be bound (Sigurosson 1997, Roberts \& Roussou 2002). Such hypotheses make wrong predictions for empirical paradigms that include stylistic fronting or excorporation. Moreover, if V2 was the result of a deep syntactic or semantic requirement, verb-first languages or verb-first orders in V2 or SVO languages should never be grammatical at the syntactic level. This is a very strong typological prediction that has not been seriously explored (but see Bury 2005, Jouitteau 2005:chap6). ${ }^{9}$

LEFT operates at a post-syntactic level and allows us to account for a possible idiosyncrasy of verb-second orders, as well as sets of erratic exceptions that are not reducible to the presence of a syntactic head before the tensed verb, nor to adverb-drop in narrative contexts (see Jouitteau 2009-2018:'V1' for a range of such exceptions in Breton).

CONTEXT: Everyday it is the same thing...

E labouran va zamm douar, hag on skuizh.

Fin work.1SG my piece land and am tired

'I work my land, and I'm tired.'

Leon dialect, (Jouitteau 2009-2018:'V1')

\subsection{LEFT is not an uninterpretable feature}

LEFT is invisible to LF, and not filtered by syntax. Since LEFT does not have a semantic effect, and since it is blind to the $\mathrm{X} / \mathrm{XP}$ distinction, multiple authors have tried a syntactic agreement scenario, going from the phonological [P-] of Holmberg (2000) for Icelandic, the empty $\varphi$ sets mentioned by Grohmann, Drury and Castillo (2000), the [-Foc] of Holmberg and Nikanne (2002) for Finnish, the [ $\delta$ ] feature of Rezac (2004a) or the categorial $[u$ CAT] in Jouitteau (2005). However, LEFT does not coincide with what we know of feature checking. First, LEFT satisfaction does not seem to be possible at a distance. Instead, its very short domain of impact characterizes it. This problem can be dealt with by postulating a feature

\footnotetext{
${ }^{8}$ Thanks to Milan Rezac for pointing the idiom chunk example out to me.

9 Old Norse would seem to be a plausible counter-example for the hypothesis that verb-first orders are syntactically ungrammatical. Rögnvaldsson (1996) provides VSO examples from corpus. Haugan (2000:22)
} 
present on almost all elements; Relativized Minimality next ensures no further element is concerned. This solution creates a second problem: a potential uninterpretable feature on the tensed head would have to be absolutely blind to all sorts of features already provided headinternally. The verbal head itself or its potential clitics have all sorts of phonological or categorical features that could satisfy the uninterpretable feature on site. A third argument, developed in Lasnik (2001), states that the EPP cannot be embodied under a strong feature. Provided that features can be checked by erasure of their satisfier inside an ellipsis (of VP or IP), VP ellipsis should allow for verb-first in V2 languages. However, verb-first exceptions are obviously not related to VP ellipsis (25). A last oddity is mentioned by Rezac (2004a:481): LEFT would be "the (unique) feature whose Agree results in the Merge component of the Move operation, and in expletive base-generation". I conclude that LEFT is not at core an agreement effect, and could not be embodied under a feature checking mechanism.

\section{Crosslinguistic conspicuous LEFT effects}

In this section, I provide a survey of the typologically most salient crosslinguistic LEFT effects. This wide typology of second placement effects shows up in Fin, T or even lower in the structure, demonstrating that LEFT is not a property of a particular head in the structure.

\subsection{Classical V2 and information packaging}

LEFT makes a precise prediction about the relationship between word order and information packaging. In V2 languages, a focus or a topic, when present, have to appear in the left periphery, leading to V2 orders. LEFT is evidenced in their absence, in so-called unmarked, or wide focus sentences that still are not verb-first. The last resort dimension of LEFT and its ultra local solutions make a straightforward, crosslinguistically falsifiable prediction about the exact set of possible pre-Tense element in a given numeration: the set of possible pre-Tense elements in wide focus sentences should consist of (i) merged expletives or (ii) whatever element stands the highest in the middle field in a given derivation, which will undergo short movement across the tensed head to form a light expletive created by movement (in the sense of Homberg 2000), or finally (iii) material excorporated from the tensed head itself. 
In V2 Kashmiri, Bhatt (1999:89) notes that "subjects and adverbs can appear clause initially without any focal stress associated with them. Other non-subject arguments are permitted to appear clause initially only if they bear focal stress". This is precisely what is expected in (ii) above. Bhatt (1999:261) suggests that the temporal adverbs that can appear before Tense in wide focus sentences are directly merged in the pre-Tense position. The closest postverbal position in Kashmiri is otherwise canonically occupied by the subject, predicting its fronting in wide focus sentences.

In German wide focus sentences also, the pre-Tense element is directly fronted from the closest postverbal position, as a last resort pre-Tense filling strategy (see Fanselow 2002a,b, and Frey 2006 who adapt the generalization of Bhatt 1999 for Kashmiri V2 orders). Frey proposes (26), where we recognize the subcomponent of the EPP that LEFT isolates.

(26) $\left[\mathrm{CP}\right.$ XP $\left.\left[\mathrm{C}^{\prime} \mathrm{V}_{\text {fin }}[\mathrm{IP} \ldots .].\right]\right]$ can be derived from [C' [IP XP .... V $\left.\left.\mathrm{V}_{\text {fin }}\right]\right]$ (by moving the finite verb to $\mathrm{C}$ and) by moving XP as the highest element of IP to SpecCP (Minimal Link) just in order to fulfil the EPP requirement associated with $C$, i.e., without any additional intonational, semantic or pragmatic effects.

(Frey 2006)

Frey labels this operation 'Formal movement' and writes: "There is [in German] a mechanism by which the prefield can be filled with the highest constituent of the middle field of the same clause while preserving the semantic/pragmatic properties of the constituent and without endowing it with additional ones. Thus, this mechanism does not seem to be related to the assignment or licensing of any contentful property, but seems to be a purely formal one". Again in the empirical domain of Germanic languages, LEFT offers a new take on an old question: that of the precise location of the inflected verb in Germanic V2. A line of analysis proposes that in matrix SVO orders, the subject is unraised, and the inflected verb is lower than its C location prototypical of other V2 orders (Travis 1984, Zwart 1993 and subsequent work). The set of empirical arguments backing this proposal can as well be argued to result from LEFT preposing the subject by stylistic fronting. ${ }^{10}$

\footnotetext{
${ }^{10}$ Reduction of one rule to another goes only one way: LEFT is not reducible to the hypothesis that SVO orders in V2 languages are lower in the structure. LEFT for example accounts for the information structure associated with initial adverbs, or past-participle fronting. In Kashmiri, non-stressed preverbal elements can be subjects, and temporal adverbs pattern with them (Bhatt 1999:261). In Breton, subject oriented adverbs, non-tensed verbal heads, etc. can satisfy LEFT.
} 
In a given V2 language, verb raising can always target the same site. If the subject is the closest element on its right in the derivation, LEFT will predict its privileged access to the pre-Tense position in wide focus sentences. Another approach of the empirical domain of V2 in Germanic or Romance postulates that the specifier of the landing site for the inflected verb is a syncretic category, a projection provided with mixed A/A-bar properties (Diesing 1990 for Yiddish, Rögnvaldsson and Thráinsson 1990 for Icelandic, Rizzi 1990, 1991, Zubizarreta 1998 for Spanish, Rezac 2004a for Breton). In any language where the closest postverbal position is an A position and the pre-Tense field is A-bar LEFT indeed predicts that the preTense position should show mixed A/A-bar properties, the A properties being reduced to LEFT movement from an A position. Finally, for VSO languages with a CP domain on the left, LEFT accurately predicts that SVO will be a widely represented alternative word order (Universal 6, Greenberg 1966, see previous discussion in section 4.1).

\subsection{Japanese and Korean Scrambling}

Short distance scrambling in Korean and Japanese also falls under the predictions of LEFT. In Korean and Japanese, short distance scrambling of the object across the subject has no semantic impact. It shows A-properties and is available depending on the previous derivational history of the object, namely its Case marking (Miyagawa 2001:300, 2003). If it can be demonstrated in Korean and Japanese that Case marking brought the object in the structural closest position to the verbal head, which does not sound unreasonable, then short distance scrambling also dissolves into a LEFT effect.

\subsection{Stylistic Fronting}

In Breton and in Slavic languages, LEFT effects with lexical verbal heads appearing before their auxiliary are known under the name of Long Head Movement. In Icelandic and Faroese, LEFT effects are just another name for Stylistic Fronting. It has been extensively and carefully demonstrated that the optionally moved pre-Tense element in subject gap position in Icelandic is exactly the one brought the closest to the inflected verb at the end of the derivation, regardless of its category (Maling 1980, Holmberg 1997, 2000, 2005 and references therein). In languages that do show LEFT effects, but where a verbal head never 
happens to be the highest element of the middle field, such violations of the Head Movement Constraint should never occur. ${ }^{11}$

Deriving V2 as a LEFT effect thus first obtains an empirical predictive power. The gain is also theoretical for two reasons. First, as already pointed out, it is desirable that two well defined but unmotivated mysteries could dissolve into one. Second, V2 is derived without appealing to a counting operation. It is rather unclear how language structures could be sensitive to positions determined by counting elements/positions. No language of the world is has obligatory V3 or V5, and no language shows verbal heads assigning Case to their internal argument if and only if they are located two positions away from it. Instead, language structures, in different modules and especially in the PF branch, are sensitive to the notion of edge. This means that second positions do not exist by themselves, but first positions do, and may be avoided, indirectly leading to second position effects. Morphological obligatory exponence derives V2 orders without appealing to a 'second position' as such, because V2 is merely a byproduct of avoidance of verb-first.

\subsection{Verb-doubling in Basque and Gungbe}

Basque and Gungbe show that prototypical LEFT effects are not restricted to the CP domain. Elordieta and Haddican (2016) present a case of ultra-local verb-doubling in Western Basque as in (27) where the verb is in T. Only the rare verbs that can raise to T can double. Doubling show all the signs of a last resort operation to prevent a ban on Tense-first. As in Breton, Hanging topics higher on the left do not interfere with the paradigm and pertain to the next phase.

Ibil-i dabil beti kale-a-n.

Western Basque

walk.inf walk.3SG always street.the.loc

'She is/IS always WALKING in the street.'

Elordieta and Haddican (2016:223)

\footnotetext{
${ }^{11}$ Kashmiri may show apparent violations of the HMC, as illustrated below from Bhatt (1995:2), with a fronted verb and a stranded realized object. Bhatt does not comment on it. More work on this construction is in need in order to determine that the verb that crossed the auxiliary head is indeed a head, as it seems here.

(i) divan chu ram shamas kitab. Kashmiri give+prog. be+prs. Ram Sham + infl. book 'Ram is giving Sham a book.'
} 
I have considered so far only examples where LEFT, like in Breton, is relative to the Tense/agreement inflection head. V2 languages however do not exhaust the empirical domain showing a salient LEFT. Gungbe provides a case of obligatory exponence also in the preverbal position, but independently from Tense, inside a nominalized small clause structure. This small clause is either selected by an aspectual control verb ('refuse', 'begin'), or by a purpose marker gbé or by a final low-tone (noted NR). In (28)b, I represent the derivation proposed by Aboh (2009) for these structures: the internal argument of the purpose marker gbé fronts into its specifier. The position of obligatory exponence is at the left edge of this moved constituent. The canonical element in preverbal position is the internal argument (here in bold), whose preverbal movement is neither case-related (Aboh 2005:158), nor related to information packaging (Aboh p.c.). ${ }^{12}$

(28) a. Àsíbá wá [A $\mathrm{A}_{\mathrm{SPP}}$ lésì dù ] gbé $\ldots$.

Asiba come rice eat PRT

'Asiba came in order to eat rice.'

b. [AspP wá [FP

[F gbé $\mathrm{t}_{\mathrm{AsPP}}$

$$
\left.\left.\left[\mathrm{A}_{\mathrm{SPP}} l \varepsilon_{\varepsilon s i}^{\prime}\left[\mathrm{Asp} d \grave{u}\left[v \mathrm{P}_{\grave{A s i b a ́}}\left[\mathrm{v}_{\mathrm{EXT}} \mathrm{t}_{d \grave{u}}\left[v \mathrm{P}\left[\mathrm{VP} \mathrm{t}_{d \grave{u}} \mathrm{t}_{l \dot{\varepsilon} \dot{s}}\right]\right]\right]\right]\right]\right]\right]\right]
$$

When this obligatory exponent position is empty, because the verb is intransitive, or because the object is either a pronominalized clitic or $A^{\prime}$-extracted, another element has to take its place and front preverbally. This element can be a locative PP (29), a reduplicated adverb like $d \dot{d} d \dot{\varepsilon}$, 'slowly' (30), a goal argument of a double object construction (31). A reduplication process of the verb is also an available last-resort strategy (32). When the numeration independently provides a preverbal head that satisfies LEFT, no fronting operation is required and the sentence is licit: presence of the prospective marker ná for example saturates LEFT effects, as illustrated in (33).

Àsíbá tò

Asiba PROG

$$
\text { [ àxì mè yì ] ' . }
$$$$
\text { market in go-NR }
$$

\footnotetext{
12 Aboh (2005) labels the preverbal position the 'subject position'. The term is induced by his analysis that preverbal movement is EPP-triggered. Aboh (2009) clearly shows that no subject ever stops in AspP where it would fail to receive Case. The Tense marker, whenever realized, is the [+futur] morpheme ná. It distributes Direct Case and is located higher in the structure (Aboh 2005:ex 11).
} 
'Asiba is going to the market.'

(30) Àsíbá tò

[ déd $\mathbf{\varepsilon} \quad$ zòn ] '.

Asiba PROG

slowly walk.PRT

'Asiba is walking slowly.'

(31) Été wè à tò [ Kòfí kplón ]n'?

Gungbe, Aboh (2009:12)

what FOC 2SG PROG Kofi teach. PRT

'What are you teaching Kofi?'

(32) Kòfí ná nò tò [ qùdù-ì ] '.

Gungbe, Aboh (2005:158)

Kofi FUT HAB PROG eat.eat-3SG NR

'Kofi will be habitually eating it.'

(33) Kòfí ná nò tò [ ná dù-ì ] .

Gungbe, Aboh (2005:158)

Kofi FUT HAB PROG PROSP eat-3SG NR

'Kofi will be habitually about to eat it.'

\section{Inconspicuous LEFT effects}

In this section, I investigate the paradigms where the satisfier of LEFT is less conspicuous than above. I design a brief typology of inconspicuous elements. The hotly debated question of null expletives is discussed in detail in section 5.5.

\subsection{Topic-drop}

The first range of inconspicuous syntactic elements satisfying LEFT is illustrated in the well documented cases of topic-drop in V2 languages, like in Breton (34) or Dutch (35)a. Dropping of a non-argument is a harder case, with less obvious evidence for the gap. Adverbdrop in (35)b and c illustrates isolated V1 patterns in joke introduction or narrative in prototypically V2 Dutch. Similar adverb drop is also noted in Breton (Gros 1984) where an adverb like so can be dropped. ${ }^{13}$

$$
\text { ... a zo gwir! }
$$

Breton

Fin is true

'That's true!/...which is true!'

\footnotetext{
${ }^{13}$ See also (Bhatt 1999:116) for examples of V1 examples with topic-drop in Kashmiri, or Sigurdsson (2010:182) for Icelandic.
} 
.... want I PRT do

'That is ok with me.'

b. $\quad$... Zitten twee mannen in de kroeg.

joke-introduction

... sit two man in the pub

'There are two men in the pub.'

c. $\quad .$. Zegt die een tegen de ander:

narrative $V I$

... says that one to the other

'The one says to the other:'

\subsection{Phonologically empty elements}

Phonologically null elements of all sorts are inconspicuous LEFT satisfiers. Icelandic and Faroese PRO subjects of infinitives are incompatible with Stylistic Fronting (Sigurosson 2008:444), and hence plausibly saturate LEFT effects. In Icelandic and Faroese tensed domains, Stylistic Fronting appears optional when it occurs in a subject gap position. I assume A-bar movement of subjects can optionally raise in SpecIP where it will leave a trace or a copy whose presence serves as a LEFT satisfier at the interface (A-bar moved objects never leave a trace there). Icelandic embedded $\mathrm{C}-\mathrm{V}$ orders are restricted to impersonal subjects (Sigurosson 2010:184), pointing toward an element licensing an impersonal pronoun. Across both pro-drop (36) and non pro-drop (37) Romance languages, a realized expletive has an acceptable null counterpart in some specific constructions. Possible realization of the expletive is a strong argument for the presence of a null expletive in the alternative.

(Ello) parece que no hay azúcar.

It/ pro $^{\mathrm{EXPL}}$ seem.3SG that no existential sugar

'It seems there is no sugar.'

Dominican Spanish, (Toribio 1996: 422)

$$
\begin{array}{ll}
\text { (Il) } & \text { faut chanter. } \\
\text { It/ } \text { pro }^{\text {EXPL }} & \text { need.3SG to.sing }
\end{array}
$$

'One/we must sing.'

From the above, it is clear that LEFT is not concerned with the PF realization of its satisfiers, and hence cannot be derived by any form of a Hearability/Visibility Condition. 
Phonologically null LEFT satisfiers are however constrained: short-movement is not an available option for them. ${ }^{14}$

\subsection{No short-move of phonologically empty elements}

Stylistic Fronting targets specifically the closest post-Tense element with phonological features. In Breton, Stylistic Fronting is insensitive to the intervention of an empty category such as the trace of an incorporated subject pronoun, or the trace of verb-movement in $\mathrm{T}$ (Jouitteau 2005:chap5). The idea that phonologically null elements cannot be fronted is also falsifiable in pro-drop languages. Old French was a pro-drop V2 language. However, the null pronouns that one finds in the IP domain appear banned from the pre-Tense area (Adams 1987). If V2 is understood as a LEFT effect, and if phonologically null elements cannot be targeted by LEFT short-movement, the ungrammaticality of unmarked pro-dropped SVO orders follows. ${ }^{15}$ I see two reasons for the ban on the short-move of phonologically empty elements. First, as noted by Rezac (2004a), empty categories cannot undergo Move because the pied-piping operation is not defined for them (Chomsky 2001:23-4), and second, fronting of a null category would fail to impact either directly or indirectly at least one of the interfaces (Jouitteau 2005).

To summarize so far, topic-drop, copy or traces, as well as null pronouns like PRO and pro are inconspicuous elements able to satisfy LEFT. Stylistic Fronting of null elements is banned by independent principles.

\subsection{C heads and even more inconspicuous elements:}

We have seen that heads are potential LEFT satisfiers. I show here that C heads, especially evidential heads, can show up with a rather unconventional morphology. They can be realized by (i) minimal sounds, (ii) ostensible physical gestures or (iii) intonation. The typology of inconspicuous LEFT satisfiers has to be extended in accordance.

\footnotetext{
${ }^{14}$ Platzack (1998) explored the idea of a Visibility Condition on the CP area for V2. The multiplication of the projections of the extended CP domain à la Rizzi (1997) made it untenable, but the intuition is reworked out in Roberts and Roussou (2002) who proposes as a parameter that some functional projections (noted *) be obligatory overt, minimally by the Spec or head. However, this rule cannot predict that phonologically null elements under the 'glass ceiling', like dropped topics or null pronouns can satisfy LEFT.

${ }^{15}$ A reviewer reports the same situation to arise in Kashmiri (Wali and Koul 1997). However, I could not find an empirical illustration for it. Wali and Koul (1997:85, ex6) shows that the preverbal expletive can be dropped, and that a stylistic fronting option is possible. Ungrammaticality of verb-first is probably assumed.
} 
SVO Modern Nantais French shows a surprising paradigm that enforces the phonological realization of a pre-Tense element. Nantais French is a non-pro-drop Romance language where null expletives as in (37) are lexically restricted. However, pre-Tense subject drop is possible like in (38) if and only if another element with phonological content is realized before the verb (Jouitteau 2004). In (38), the weak pronoun 3PL ils is pronounced with a final /z/ in order to accommodate the initial vowel of the inflected verb. If this /z/ liaison remains, the subject can be freely dropped. More importantly, the liaison can be erased together with the weak pronoun if and only if any another phonological matrix is realized before the verb.

(Ils) /z/ ont arrêté plus de 150 militants bretons.

they LIAISON have arrested more than 150 militant breton

'They have arrested 150 breton militants.'

Erasure of both the subject pronoun and its liaison are licit if pronunciation of the inflected verb is preceded by a disabused/pfff!/ sound or an admirative whistle. These minimal sounds unambiguously express the attitude of the speaker toward the utterance. These minimal sounds realize an evidential head in the CP domain (Jouitteau 2004, 2005:chap6). ${ }^{16,17}$

Syntactic null $\mathrm{C}$ heads are also eligible LEFT satisfiers. A first case is a phonologically null head that is detectable because it syntactically licenses another. Licensing of negative polarity items such as ever in English can serve as a detection test for a class of inconspicuous preTense elements. In English, the adverbial ever must be licensed by an element higher in the structure ('If he should ever call', see Klima 1964, Giannakidou 1997). A pre-Tense inconspicuous element is detectable when it licenses ever : Ø Will he ever call or $\emptyset$ Should he ever call, she will answer. Likewise, in yes/no question, a null Q head precedes the inflected verb and leads to inconspicuous V2. Such paradigms are called verb-first in prototypical V2 languages as in (39)a, or inversion contexts in prototypical SVO as in (39)b. The yes/no question pattern could also be analyzed by a verb-raising operation, the inflected verb providing a phonological matrix to an abstract head. In this scenario, the inconspicuous

\footnotetext{
${ }^{16}$ The Nantais French $\mathrm{C}$ head is not the LEFT satisfier itself, but it allows for erasure of the LEFT satisfier subject at PF. At PF, erasure of the subject is licit only if it is directly preceded by a realized head, a constraint that has been independently argued for (Ackema and Neeleman 2003, Bošković 2007). This accurately predicts that LEFT short-movement never occurs as a repair strategy with non-realized subjects. Stylistic Fronting, among others, is out: *Arrêté ont plus de 150 militants bretons.

${ }^{17}$ See also Santorini (1989:48), ex (18) for an example of English subject drop repaired by a pre-Tense yeah.
} 
element is a $\mathrm{C}$ particle on which the verb has incorporated. Such particles triggering inconspicuous V2 orders are to be found overtly in Breton. Only some rare verbs can select a matrix $\mathrm{C}$ head as in (39)c, associated with the rare apparent verb-first orders in the language. In Welsh, pre-Tense matrix $\mathrm{C}$ particles can be merged freely, a property that qualifies the socalled prototypically verb-first Welsh as verb-second ((39)d).
a. Ga je met mij mee?
Q go you with me PRT
'Do you come with me?'
b. As-tu jamais aimé?
Q have-you ever loved
French
c. E-maon er ger.
C-be.1SG in.the home
Breton
'I am home.'
d. Fe glywes.
C heard.1.SG
'I've heard.'
Welsh

Dutch, (Bennis 2006:fn3)

Last but not least, the morphology of inconspicuous syntactic heads can be oral, but also gestural, taking from a morphology that is more prototypical of sign languages. Going back again to Nantais French, we saw that PF erasure of a pronominal subject was possible if and only if this subject was preceded by an evidential head realized at PF. We saw already that minimal sounds can realize evidentiality markers standing in the A-bar field. Surprisingly, these markers can also be realized by an ostensible physical gesture as in (40)a, b (Jouitteau 2004, 2005:chap6, 2005c). In (40), if the gesture fails to be produced, the sentence is felt strongly ungrammatical. In (40)c, licit with falling intonation, the gesture realizes a $Q$ head serving clause typing.

(40) a. ([SHOULDER RAISING])* rappellera plus tard.

Nantais French

$$
\text { call.back later }
$$

'(it doesn't matter:) you/he/she/we will call back later.'

b. ([EYEBROW RAISING])* prendront le car de six heures.

will.take the bus of six hour 
'(I doubt that) they will take the six hour bus.'

c. ([HEAD RAISING $])^{*} \quad$ sens le gaz?

smell the gaz?

'Do I smell like gaz (or what)?' > 'Come closer!'

In (40)c, if and only if a raising intonation is realized and serves clause-typing, the gesture becomes optional. Realization of pre-Tense Q particles by raising intonation is another wide spread crosslinguistic source of inconspicuous elements satisfying LEFT.

\subsection{Raising calmly the question of phonologically null expletives}

The three recurrent serious questions about null expletives concern their theoretical motivation with respect to economy, leading to questions of learnability.

(41) i. Can linguists postulate syntactic elements that have neither phonological realization nor semantic content? Isn't it completely ad-hoc, especially in pro-drop languages?

ii. Elements enter a numeration if and only if they have an effect on the interface (Chomsky 1995:294).

iii. How is a null and semantically empty element learnable? ${ }^{18}$

I agree with the idea that if a null expletive fails to have impact on at least one of the interfaces, it may exist without being falsifiable and is not in our scientific reach. However, I consider that null expletives, contrary to the presupposition of (41), can have an impact on at least one of the interfaces. Requirement of impact should be saturated by an indirect impact. To provide an astronomy analogy, the presence of the invisible satellite of a planet can be revealed by the gravity influence this satellite has on its planet. Likewise, if phonologically null and semantically empty elements do exist in syntax, they should be revealed by the result of their interactions with other syntactic elements, at least on one of the interfaces. Null expletives should thus either have an effect on other elements (phi feature sharing, consonantic mutation on the following element, disturbance of liaison...), or they should impact the semantic behavior of other elements (scope variations, indefiniteness effects, restriction on the type of verb, licensing of negative polarity items or free choice). Sheehan

\footnotetext{
${ }^{18}$ The argument of learnability is valid only in the hypothesis that LEFT is a Parameter. If LEFT turns out to be a Principle, learnability is not an issue.
} 
(2006:238) shows for instance that in Romance languages, a null locative can have subtle effects on the semantics of the sentence like there does, and is interpreted at LF as an existential quantifier. This null expletive also has an impact on word order: it is responsible for inversion in out-of-the-blue contexts.

Below, I illustrate specifically with a class of null expletives revealed by the disturbances they trigger on agreement paradigms.

\subsection{A case of indirect evidence for pre-Tense null expletives: Agree}

We know for a fact that overt expletives can enter into $\varphi$-feature relations with an inflected verb (It seems that the girls are having fun). Czech provides a full paradigm of expletives agreeing in number and gender. Morphology here overtly signals the expletive's interpretable $\varphi$ features (Rezac 2004b). These elements enter into agreement relationships with their verbs the way pronominal subjects do.

Von (asi) byl dřív vchod he probably was before entrance.NOM from other side 'There probably used to be an entrance on the other side.'

Vona se každýmu dítěti $\quad$ jeho první hračka líbí.
she SRX every-DAT child-DAT its first toy pleases
'Every child likes its first toy.'

In pro-drop languages like Iberian Spanish or Italian, the verbal agreement morphology is provided with a $[3 \mathrm{SG}]$ set of features. In languages or constructions with optionality of the realization of the expletive, the agreement pattern is constant irrespective of the pronunciation of the expletive, as previously illustrated in (36) and (37). In this case, null expletives are probably uniformly the goals for Agree. The concurrent hypothesis that null expletives are not eligible goals for Agree has to resort to the idea that the verb $3^{\text {rd }}$ person agreement is default (and has to parameterize it), with the implication that modifications of a verbal root outside of agreement paradigms is possible. Absence of a pronominal expletive should trigger the inflected verb to either show up with a bare root, or to covary with the closest element providing interpretable $\varphi$-features. This pattern is not observed.

The interesting case is that of languages where the null expletive is not the subject. Such a case is provided by transitive expletive constructions in languages where a realized subject 
shows up postverbally and a LEFT satisfier, distinct from the subject, shows up before Tense. I assume that in these languages too, pre-Tense expletives can bear interpretable $\varphi$-features and be a goal for Agree. When the expletive is the closest goal for Agree, it should act as an intervener for subject agreement and perturb the verbal covariance with the features of the post-Tense subject. I propose the hypothesis in (44), which has far reaching typological consequences as it allows for a reclassification of emblematic 'verb-first' languages with impoverishment agreement paradigms like Irish, Welsh, Modern Standard Arabic and Hebrew. They would be at core inconspicuously verb-second.

(44) A null expletive is recoverable and learnable when it is a goal for Agree.

I follow Jouitteau and Rezac (2006) who propose that the 'frozen agreement' characteristic of complementarity effect in Celtic, Arabic and Old Hebrew results from the presence of an intervener for Agree, as illustrated below for Modern Standard Arabic.

a. /akal-na

V-psubject

have eaten.3F.PL

'They have eaten.'

b. * /akal-na

/al-ummahat-u

*V-psubject Subject

have eaten.3F.PL the mothers.F.PL-NOM

c. /akal-at

/al-ummahat-u

V- $\varphi$ 3SG

Subject

have eaten.3F.SG the mothers.F.PL-NOM

'The mothers have eaten.'

Modern Standard Arabic

In the Minimalist Program, a Probe $[u \varphi]$ tracks interpretable features and 'agrees' with the closest goal. In (44), the Probe $[u \varphi]$ on the inflected head has found a goal with interpretable [3SG] features, and covariance with the subject is not available anymore. The agreement morphology spells out [3SG] features whatever the features of the DP subject because the closest goal for the Probe indeed has $[3 \mathrm{SG}]$ interpretable features: the pre-Tense expletive. In (44)a, the weak pronominal subject incorporates into the inflected head and consequently stays the closest goal for Agree. The location and precise features of the null expletive can now be investigated: (46) shows that the expletive is closer to the inflected verb than a 
hanging topic (or any other null element bound by this hanging topic), and (47) shows that the intervening expletive is not specified for gender ${ }^{19}$.

$$
\text { al-nisaa?-u ya-Zhar anna-hunna Zahab-na Ali (1996) }
$$

the women3F.PL-NOM seem-3SG.M that-they-F left-3F.PL.

'As for the women, it seems that they have left.'

LEFT Modern Standard Arabic, Doron (2000:77)

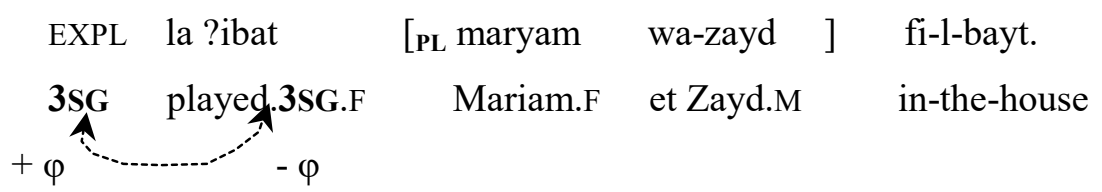

'Mariam et Zayd played in the house.'

Irish is a pro-drop VSO language, a prototype in the literature of a language not showing any sort of EPP effect (McCloskey 1996). My hypothesis in (44) accurately predicts that complementarity effects and apparent absence of LEFT effects go hand in hand: the pre-Tense null [3SG] goal for Agree monotonously saturates LEFT. In Irish, the pre-Tense null C head has interpretable $\left[3 \mathrm{SG}\right.$ ] features and monotonously freezes agreement at the syntactic level. ${ }^{20}$

(48) EXPL Chuirfeadh [PL na léachtóiri ] isteach ar an phost sin.
$+\varphi$ 3SG would-put.3SG [PL the teachers ] in for the job that
'The teachers would apply for that job.'

Rich morphology of Irish agreement thus differs from that of Modern Standard Arabic. The latter results from a syntactic agreement with the subject, whereas the former is monotonously frozen at the level of syntax. Irish rich agreement morphology is a post-syntactic realization superimposed onto the monotonous syntactic frozen [3SG] agreement morphology. As such, it shows idiosyncratic properties and is sensitive to prosody (see Adger 2006). The Modern Irish pre-Tense expletive is otherwise of the Breton bez' type in that it imposes no restriction on the post-Tense subject. The null Irish matrix $\mathrm{C}$ head has to be present in all Modern Irish

\footnotetext{
${ }^{19}$ The literature diverges as to whether gender marking on the inflected verb is a result of cliticisation or of agreement in Modern Standard Arabic. My hypothesis is immune to the controversy.
} 
sentences, independently of LEFT, because the agreement pattern is not troubled by independent LEFT satisfaction. Early Celtic also provides the case of a null matrix $\mathrm{C}$ head with a LEFT last resort dimension: in Brythonic Celtic of the $\mathrm{XI}^{\text {th }}$ century, a special so-called 'absolute' agreement marker correlates with the only possible V1 orders of the language (on Bergin's law, see Fleuriot 1983).

chwerdyt bryt wrth a garo Early Welsh, [Red book, 1028.12] laugh.V1 spirit $\mathrm{P}$ Fin likes

'The spirit laughs at what it likes.'

In (49), absolute agreement is realized by the $-y t$ agreement morpheme. I propose that LEFT is active in the language: in Tense-first contexts, it triggers the last resort Merge of a null expletive (possibly a $\mathrm{C}$ head) whose interpretable features trigger the $-y t$ agreement reflex. Consistent with this hypothesis, Early Welsh realized $\mathrm{C}$ heads or fronted focused elements are incompatible with this special $-y t$ agreement. ${ }^{21}$

Below, I detail the three possible scenarios opened by the existence of null expletives, and the predictions they make: The main three options are : (i) when a null expletive intervenes for Agree, (ii) when a null expletive does not intervene for Agree, and (iii) when no null expletive is available in the language.

In the first case, the null pro expletive intervening for Agree is detectable and learnable by the disturbance of agreement it triggers on the verbal morphology. If this intervener for Agree stands in a pre-Tense position, it also leads to apparent verb-first orders that are inconspicuously Tense-second. If freely available, this expletive should ban any other LEFT satisfaction strategy in the language. Irish or Modern Standard Arabic could illustrate such a scenario. In this line of reasoning, 'poor agreement' becomes a sign that LEFT has been satisfied by a syntactic element bearing default features. In case a null expletive is available in the language but never is the closest goal for Agree, or if it does not bear interpretable features, this null expletive does not intervene in agreement relationships and no

\footnotetext{
${ }^{20}$ Celtic languages have overt matrix $\mathrm{C}$ particles. The Irish intervener for Agree is plausibly a null matrix $\mathrm{C}$ head. $\mathrm{C}$ heads can bear interpretable phi-features as in Flemish.

${ }^{21}$ Note that my predictions in Celtic mirror exactly the predictions of Alexiadou and Anagnostopoulou (1998). Their hypothesis that the EPP is a requirement satisfied by rich agreement wrongly predicts that Celtic
} 
complementarity effect is expected on the verbal agreement system. LEFT is monotonously satisfied by this null expletive. The overt counterpart of this scenario is illustrated by transitive expletive constructions. In order to be learnable, this null expletive should impact one of the interfaces by other means like association with another element (for example definiteness effects, restriction to person 3...). In case (iii), no null expletive is available in the language. If complementarity effects do show up, they are triggered by another sort of intervener for Agree, as is the case in Breton where the intervener is the extended $v \mathrm{P}$ itself (Jouitteau and Rezac 2006), or by some other mechanism. Apparent V1 orders should be banned, because LEFT is never satisfied by a pre-Tense null intervener for Agree. All sorts of conspicuous LEFT strategies characterize the language, leading to a salient V2 word order. ${ }^{22}$

\subsection{Null expletives and excorporation}

We know from Breton analytic tenses in do support and verb-doubling constructions that LEFT effects include excorporation out of a complex morphological head like that of a tensed verb. This paves the way for another excorporation scenario, where the bundle of features that are excorporated from the tensed verbal complex is not the lexical verb and its potential clitics, but the nominal features of agreement. This recalls Kim (2004)'s proposal that null expletives can be realized by features splitting and subsequent pre-Tense movement. Kim presents evidence in Greek, Italian and Spanish for a pre-Tense null expletive. First, a postTense null subject can control the PRO subject of an infinitival $v \mathrm{P}$ adjunct. The null subject being in situ, inside the $v \mathrm{P}$, could not $\mathrm{C}$-command a $v \mathrm{P}$ adjunct, revealing a higher pronominal element $\mathrm{C}$-commanding the adjunct.

In conclusion, I call for a drastic and careful extension of the typology of inconspicuous elements potentially satisfying LEFT. First, elements realized by gestures or minimal sounds or intonative morphology do exist as LEFT satisfiers and have to be seriously considered. Second, null expletives do exist, and can bear interpretable features that are selected as a goal for Agree. Depending on their location, they should be able to intervene in verb-subject agreement relationships by Relativized Minimality. There seems to be languages where intervention scenarios could provide a key for the study of agreement troubled/impoverished 
paradigms, as well as for word order. The above empirical body of data is too partial to be considered definitely conclusive on that last point, but it is enough to conclude that the study of inconspicuous expletives is a challenge of the sort we should not refuse. Furthermore, the study of inconspicuous expletives created at PF bears the potential of raising the question of the very existence of verb-first languages, and redesigns the classification of human languages.

\section{A wider typology of verb-second languages}

LEFT satisfaction at a postsyntactic level derives a uniform X(P)-VSO type in all languages with a CP domain on the left and with a raised verbal head bearing Tense and agreement features in $\mathrm{T}$ (or subsequent raising to Fin). In this empirical domain, word order further depends on the Case assignment system and the lexical inventory of a given language, leading to either an SVO, VSO or V2 type. I detail below these three different cases.

In an X(P)-VSO language where the pre-Tense position is filled independently of LEFT, for example because direct Case is assigned to the subject into the left position of Tense, Case distribution and LEFT conspire to impose the presence of a nominal element. Such an X(P)VSO language over-represents SVO orders, as is the Case in English or French. Apparent V1 orders are inconspicuouly V2, and are restricted to the exact set of null pronominal elements that fill in the pre-Tense position, like null first person pronoun in English declaratives (diarydrop), null second person pronoun in English interrogatives ( ø bought milk?), or restricted null expletives in French as in (37) and (38). Should the ICF requirement vary across time, the language shows conspicuous V2 effect as illustrated by stylistic fronting in the V2 stage of Romance languages. ${ }^{23}$

In an $\mathrm{X}(\mathrm{P})$-VSO language where the pre-Tense position is not filled independently of LEFT, and where the lexicon provides inconspicuous strategies to satisfy LEFT (pro-drop, null C expletive, gestural expletive), canonical word order can superficially look V1. Irish, Scottish Gaelic, Welsh, Biblical Hebrew or Modern Standard Arabic show a wide inventory of

\footnotetext{
${ }^{22}$ Null pronominals are not available in Breton, which is not a pro-drop language. Breton null subjects are plausibly traces of incorporation into $T$. The preverbal position is occupied by a null subject only in case of topic-drop, under regular restrictions of interpretability.

${ }^{23}$ The term residual V2 for SVO languages is thus inaccurate in synchronic studies: SVO fully instantiates V2.
} 
inconspicuous pre-Tense elements (heads or phonologically empty elements), leading to their VSO appearance. Crosslinguistically, those inconspicuous V2 orders derive from the set of properties already typologically associated with verb-first languages (pro-drop parameter or pre-Tense particles, see Carnie and Guilfoyle 2000:10, Carstairs-McCarthy 1999:158, Bury 2002).

Finally, an X(P)-VSO language where the pre-Tense position is not filled independently by LEFT, and whose lexicon fails to provide inconspicuous satisfaction strategies will resort to visible heads or XPs to fill in the pre-Tense position. These languages are the classical V2 languages. The lexicon of Germanic languages prototypically lacks null subjects and matrix $\mathrm{C}$ heads. The inventory of pre-Tense elements consequently consists of either a pronounced phrasal constituent, a topic-drop as was illustrated for Dutch in (35), or an embedded C head. As for expletives, German has an overt expletive es for meteorological verbs, and a null expletive for existentials, but the latter seems correlated with inversion (Sheehan 2006:239), which points towards a postverbal null expletive that could not be fronted as a LEFT satisfier due to its lack of phonological content. In Breton, matrix $\mathrm{C}$ or $\mathrm{Q}$ heads and some restricted matrix $\mathrm{C}$ heads are available as in (39)c, and they design the limited set of superficial V1 orders (C-VSO). I recapitulate the inventory of LEFT satisfiers in the table content below. Crosslinguistic inconspicuous LEFT satisfaction appears in grey.

\begin{tabular}{|c|c|c|c|c|c|c|c|c|c|}
\hline \multirow{2}{*}{$\begin{array}{c}\text { Satisfaction of the EPP } \\
\text { by : }\end{array}$} & \multicolumn{3}{|c|}{ SVO } & \multicolumn{3}{|c|}{ VSO } & \multicolumn{3}{|c|}{ V2 } \\
\hline & English & French & Italian & "Welsh & Irish & Arabic & $\begin{array}{l}\text { Hebrew } \\
\text { (Mod.) }\end{array}$ & Breton & German \\
\hline DP subject & $\sqrt{1}$ & $\sqrt{1}$ & $\sqrt{1}$ & $\sqrt{1}$ & $\sqrt{1}$ & $\sqrt{1}$ & $\sqrt{ }$ & $\sqrt{1}$ & $\sqrt{1}$ \\
\hline Realized Expletive & $\sqrt{ }$ & $\sqrt{ }$ & $\sqrt{ }$ & $\sqrt{ }$ & $\varnothing$ & $\sqrt{ }$ & $\sqrt{ }$ & $\sqrt{ }$ & $\sqrt{ }$ \\
\hline DP object & - & - & & $\sqrt{ }$ & & & $\sqrt{ }$ & $\sqrt{ }$ & $\sqrt{ }$ \\
\hline Loc Inversion & $\sqrt{ }$ & $\sqrt{ }$ & & $\sqrt{ }$ & & & $\sqrt{ }$ & $\sqrt{ }$ & $\sqrt{ }$ \\
\hline Pre-Tense Adv & & $\sqrt{ }$ & & & $\sqrt{ }$ & & $\sqrt{ }$ & $\sqrt{ }$ & $\sqrt{ }$ \\
\hline Null Expletive & $\varnothing$ & Restrict. & $\sqrt{ }$ & $\varnothing$ & $\sqrt{ }$ & $\sqrt{ }$ & $\sqrt{ }$ & $\varnothing$ & Restrict. \\
\hline null subject Pronom & $\varnothing$ & $\varnothing$ & $\sqrt{ }$ & $\sqrt{ }$ & $\sqrt{ }$ & $\sqrt{ }$ & $\varnothing$ & $\varnothing$ & $\varnothing$ \\
\hline $\mathrm{C}$ head in embedded & - & - & - & $\sqrt{1}$ & $\sqrt{7}$ & $\sqrt{1}$ & $\overline{1}$ & $\sqrt{1}$ & $\sqrt{7}$ \\
\hline $\begin{array}{c}\text { Null C head in } \\
\text { embedded }\end{array}$ & - & - & - & & & & & $\sqrt{ }$ & \\
\hline Matrix C head & $\varnothing$ & $\varnothing$ & $\varnothing$ & $\sqrt{ }$ & $\sqrt{ }($ morph $)$ & $\sqrt{ }$ & & $\sqrt{\text { few }}$ & $\varnothing$ \\
\hline $\begin{array}{c}\text { Expletive of Stylistic } \\
\text { Fronting }\end{array}$ & & & & & & & & $\sqrt{ }$ & \\
\hline $\begin{array}{c}\text { non segmental gestural } \\
\text { EXPL }\end{array}$ & & $\begin{array}{l}\sqrt{\text { (Nantais }} \\
\text { French) }\end{array}$ & & ? & & & & ? & \\
\hline
\end{tabular}


The X(P)VSO classification thus subsumes the SVO, VSO and V2 types. Family internal word order partitions are avoided. The V1 vs. V2 typology classifies apart languages whose genetical links are obvious and whose core properties are alike: in the Celtic branch, Modern Irish, Welsh, Scottish Gaelic and Manx are considered V1 whereas Middle Welsh, Breton and Cornish are considered V2, and Old Irish residual V2. In the Semitic branch, Biblical Hebrew and Modern Standard Arabic are classified in the V1 type whereas their modern counterparts, Modern Hebrew and various Arabic dialects are V2. The word order of the X(P)-VSO subtypes is now clearly tied with the availability of inconspicuous strategies for LEFT satisfaction. Identifiable changes in the lexicon produce changes in superficial word order. For example, the diachronic switch from V2 to V1 in Middle Welsh directly follows from availability of a matrix particle as illustrated in (39)d. (see Willis 1998, Bury 2002). Loss of V2 in Old French coincides with the loss of an inconspicuous element (a null subject, Adams 1987). The X(P)VSO type derived by LEFT embraces typical SVO languages, V2 languages, as well as those V1 languages that are reclassified as inconspicuously V2.

Finally, another consistent set of languages typologically classified as verb-first, also seem to be derived by LEFT. In these languages, verb-raising amounts to remnant predicate fronting. LEFT, if any, is satisfied by the verbal XP structure itself. In verb-first languages like Niuean or Chol, it is thus movement of the remnant VP that saturates LEFT (they are PredP-SO or PredP-OS languages, see Carnie, Dooley-Collberg and Harley 2005, Sifaki 2003, Massam 2005, 2010 and references therein). Following the estimations of Tomlin (1984), 9.6\% of the languages of the world are actually classified as V1 languages. The very existence of V1 languages (, or of any syntactically verb-first order in any type of language) would of course provide a solid argument against LEFT as a Principle. However, as seen above, an independently necessary extension of the typology of expletives, particularly of null expletives, sets up the exploratory conditions for (51).

Strict V1 orders/languages are ungrammatical objects.

Languages whose word order is not affected by LEFT are the languages with a CP domain on the right like some Dravidian languages (Telugu, Tamil, Kannada, Malayalam, cf. Bayer 1999), or Austronesian languages (Seedicq, cf. Holmer 2005). The paradigms are more complicated in the languages that have a CP domain partially on the right and partially on the left like Basque, or some Southern and/or Eastern Indo-Aryan languages in close contact with 
Dravidian languages like Bengali, Oriya, Assamese, Marathi, Dakkhini Hindi (cf. Bayer 1999).

\section{Conclusion: summarizing what LEFT is and is not}

LEFT is the trigger for late insertion of an obligatory exponent in post-syntactic morphology. In the history of the Extended Projection Principle, LEFT addresses the subcomponent that cannot be reducible to either Case effects or phi-checking relationships. LEFT is satisfied by way of internal or external Merge. It is constrained by ultra-locality and shows linear effect. Idiosyncratic excorporation is an option for its satisfaction. It is related only accidentally to the notion of subjecthood, in the crosslinguistic situations where ICF and LEFT happen to require the same element (prototypically English or French, but also pro-drop languages where the null expletive serves as a goal for Agree). LEFT, being independent of subjecthood, is also not tied to the SpecIP site. It seems that LEFT is not crosslinguistically correlated with any particular functional projection. In an articulated CP domain à la Rizzi (1997), LEFT seems active in Fin in Breton (Jouitteau 2005), in Mood in Kashmiri (Bhatt 1999), Force in German, I in Icelandic, Spanish or French, Asp in Gungbe etc.

In the above, and except for Gungbe, Japanese and Korean, I have followed the intuition of Koster (2003) and Kučerová (2005), among others, that EPP effects are related to Tense. In the Tense-related LEFT paradigms however, LEFT effects could as well be regarded as related to morphological Agreement. The inquiry here should profit from close investigation of languages that express inflection, Tense or Agreement separately. Khoekhoegowab, a central Khoesan language, seems to show Agreement dependent V2 effects (Huybregts 1997, 2003, Den Besten 2002, 2007). Lecarme (1996) also observes V2 effects in Somali that are attached to $\mathrm{C}$ particles that are themselves dependent on the presence of Agreement. As far as I understand the data, these V2 effects seem of the LEFT type, which could also show LEFT effects to be dependent on the expression of agreement.

There is a typological variation as to what element is too high for LEFT satisfaction purposes (elements standing above the glass ceiling, higher than the linearized phase headed by the head showing LEFT effects). V2 languages vary as to what is the last phase of their derivation, leading to a variation in the 'glass ceiling' above LEFT effects. Rare are the V2 languages that tolerate one and only one element appearing before the tensed element (Norwegian is a candidate, but see Eide 2011). In Breton like in Rhaeto-Romance V2, the high glass ceiling isolates scene-setting adverbs and hanging topics (Poletto 2002). In 
contrast, Germanic embedded C heads obviously are not eligible LEFT satisfiers. This is not easily demonstrated in languages where the inflected verb fails to move when the $\mathrm{C}$ head is realized (German, Dutch, Swedish, Norvegian, Danish), but this is essential to derive socalled symmetrical V2 languages like Icelandic that allow for embedded C-EXPL-V orders. In Icelandic, the Force $\mathrm{C}$ head seems above the glass ceiling, rendering it invisible to LEFT effects. In Kashmiri embedded sentences, only the $k i \mathrm{C}$ head seems to stand into the glass ceiling and patterns with embedded V2, in contrast with the other embedded C heads ${ }^{24}$.

LEFT seems crosslinguistically widespread, and I propose a drastic extension of inconspicuous elements and expletives that could even reveal a wider empirical body of evidence. LEFT is a morphological Parameter, and there should be languages that do not have it, that is there should be VSO languages that are not derived by underlying VP fronting, or verb-raising into an inconspicuous matrix $\mathrm{C}$ head. As a parameter, LEFT has to be learnable. LEFT in pro-drop languages is active and learnable when the forced expletive is a goal for Agree, (i) if the expletive is the subject (as in Spanish) or (ii) if it is an intervener for Agree (Modern Standard Arabic and Modern Irish). Some V2 languages like Karitiana (Storto 2014) are areally isolated from other V2 languages, but the fact that LEFT operates in realizational morphology provides a key to understand the areal character of second position phenomena in Europe, be it clitic second in Slavic languages or V2 in Old Romance languages, Breton, Middle Welsh and Germanic languages.

\section{Acknowledgments}

Different versions of this article have benefited from comments and notes from Milan Rezac, Dirk Bury, Sam Wolfe, anonymous reviewers from NLLT, NWO, and this volume. I gratefully thank them here.

\section{References}

Abeozen, (=Fañch Elies). 1991. translation of the Mabinogion, Mouladurioù Hor Yezh. Aboh, E. 2005. Object-shift, verb-movement and verb reduplication, G. Cinque \& R.S. Kayne (eds.), The Oxford Handbook in Comparative Syntax, chapter 4.

Aboh, E. 2009. Clause structure and verb series, Linguistic Inquiry 40:1, 1-33.

\footnotetext{
${ }^{24}$ This head seems quite high in the left periphery: $w h$ movement can target the pre-Infl position under a topic (C-(top)-wh-AUX order, Bhatt 1999:160,166).
} 
Ackema, P. and A. Neeleman. 2003. Context-Sensitive Spell-Out, Natural Language and Linguistic Theory 21: 681-735.

Adams, M. P. 1987. Old French, null subjects, and verb second phenomena. dissertation University of California, Los Angeles.

Adger, D. 2006. Post Syntactic Movement and the Old Irish Verb, Natural Language and Linguistic Theory 24:605-654.

Alexiadou, A. \& E. Anagnostopoulou, 1998. "Parameterizing AGR: Word order, Vmovement and EPP-checking." Natural Language and Linguistic Theory16: 491-539.

Ali. 1996. Arabic Agreement, ms.

Anderson, S.R. 2005. Aspects of the Theory of Clitics, Oxford Studies in Theoretical Linguistics, Oxford University Press.

Ar Go, Yeun. 1950. Raklavar, Koñchennoù eus Bro ar Ster Aon, Yann ar Floc'h, Kemper, Levrdi Le Dault.

Avrutin, Serguei and Maria Babyonyshev 1997. Obviation in subjunctive clauses and AGR; evidence from Russian, Natural Language and Linguistic Theory 15:229-262.

Babby, Leonard H. 1991. Non-Configurational Case Assignment in Russian, A. J. Toribioand W. Harbert (eds.), Cornell Working Papers in Linguistics 9, Cornell University Press, Ithaca, NY, pp. 1-55.

Bailyn, J.F. 2003. "What, if anything, is the EPP?", summer courses, Egg 2003.

Bailyn, J.F. 2004. “Generalized Inversion”, Natural Language and Linguistic Theory 22:1-44.

Bayer, J. 1999. Final Complementizers in Hybrid languages, Journal of linguistics 35:2, 233271.

Belletti, A. 1988. The Case of unaccusative, Linguistic Inquiry 19: 1-34.

Bennis, H. 2006. Agreement, pro and imperatives. P. Ackema, P. Brandt, M. Schoorlemmer, \& F. Weerman, (eds.) Arguments and agreement, Oxford: Oxford University Press, 101127.

Besten, H. 2007. Absolute POS $2^{\mathrm{ND}}$ and yet with asymmetry: the case of Khoekhoegowab, presentation at the workshop on $V 1 / V 2$, Leiden.

Besten, H. 2002. Khoekhoe syntax and its implications for L2 acquisition of Dutch and Afrikaans, R. Mesthrie \& P.T. Roberge (eds.) Focus on Afrikaans Sociohistorical Linguistics. Part. II. Journal of Germanic Linguistics 14.1:3-56.

Bhatt, R. 1995. Verb Movement in Kashmiri, ed. by Roumyana Izvorski, Miriam Meyerhoff, Bill Reynolds, and Victoria Tredinnick,(eds.), Penn Working Papers in Linguistics, vol 2.

Bhatt, R. 1999. Verb Movement and the syntax of Kashmiri, Studies in Natural Language and Linguistic Theory 46, Dordrecht:Kluwer.

Boeckx, C. 2000. The EPP Eliminated. ms, Uconn.

Borsley, R.D. \& Kathol. 2000. Breton as a V2 language, Linguistics 38, 665-710.

Borsley, R.D., M.L. Rivero \& J. Stephens. 1996. Long Head Movement in Breton. The Syntax of the Celtic Languages: a comparative perspective, ed. Robert D. Borsley and Ian Roberts, 53-74. Cambridge University Press.

Borsley R.D., and J. Stephens 1989. Agreement and the position of subjects in Breton, Natural Language and Linguistic Theory 7, 407-427.

Bošković, Z. 1997. The Syntax of Non finite Complementation: an Economy Approach. Cambridge, Mass.:MIT Press.

Bošković, Z. 2002. A-Movement and the EPP, Syntax 5:167-218.

Bošković, Z. 2007. On the Locality and Motivation of Move and Agree: An Even More Minimalist Theory, Linguistic Inquiry 38,4:589-644.

Bottineau, D. 2009. Les temps du verbe Breton: Temps, aspect, modalité, interlocution, cognition - des faits empiriques aux orientations théoriques, manuscript. 
Burton-Roberts, Noel \& Poole, Geoffrey. 2006. A representational approach to stylistic fronting and verb-second in Icelandic, Special Issue Linguistic Knowledge: perspectives from phonology and from syntax, Patrick Honeybone \& Ricardo Bermúdez-Otero (éds.), Lingua 116(5): 562-600.

Bury, D. 2002. A reinterpretation of the loss of verb-second in Welsh, Syntactic effects of Morphological Change, D.W. Lightfoot (ed.), Oxford: OUP, 215-231.

Bury, D. 2003. Phrase Structure and derived Heads, PhD dissertation, UCL, London.

Bury, D. 2005. Preverbal Particles in Verb-Initial Languages, Verb-First: On the Syntax of Verb Initial Languages, Carnie, A. and Harley, H. (eds.), Amsterdam/Philadelphia: John Benjamins Publishing Company, 135-154..

Carnie, A., Dooley-Collberg \& Harley, H. (eds.) 2005. VerbFirst: On the Syntax of Verb Initial Languages, Amsterdam/Philadelphia: John Benjamins Publishing Company.

Carnie, A, \& Guilfoyle (eds.). 2000. The Syntax of Verb Initial Languages, Oxford University Press, New York.

Carstairs-McCarthy, A. 1999. The origins of complex language: An inquiry into the evolutionary beginnings of sentences, syllables, and truth. Oxford: Oxford University Press.

Chalm, E. 2008. La Grammaire bretonne pour tous, An Alac'h embannadurioù.

Chekili, F. 2004. The Position of the Postverbal Subject and Agreement Asymmetries in Arabic, Philologie im Netz 27, 35-46.

Chomsky, N. 2000. Minimalist inquiries: The framework, Martin, D. Michaels, \& J. Uriagareka (eds.), Step by step: Essays on minimalist syntax in honor of Howard Lasnik. Cambridge, MA: MIT Press: 89-155.

Chomsky, N. 2001. Derivation by phase, M. Kenstowicz (ed.), Ken Hale: A life in language, Cambridge, MA: MIT Press: 1-52.

Chomsky, N. 1995.The Minimalist programm, MIT Press, Cambridge, MA.

Chomsky, N. 1986. Barriers, Linguistic Inquiry Monograph 13. MIT Press, Cambridge, Mass.

Chomsky, N. 1982. Some concepts and Consequences of the Theory of Government and Binding. MIT Press, Cambridge, Mass.

Diesing, M. 1990, Verb Movement and the Subject Position in Yiddish, Natural Language and Linguistic Theory 8: 41-80.

Doron, E. 2000. VSO and Left-Conjunct Agreement, The Syntax of Verb Initial Languages, Carnie \& Guilfoyle (eds.), Oxford University Press, New York.

Eide, Kristin M. 2011. 'Norwegian (non-V2) declaratives, resumptive elements, and the Wackernagel position', Nordic Journal of Linguistics 14: 179-213.

Elordieta, Arantzazu \& Bill Haddican. 2016. Strategies of verb and verb phrase focus across Basque dialects, Beatriz Fernandez \& Jon Ortiz de Urbina (éds.), Microparameters in the Grammar of Basque, 221-241.

Embick, D. and R. Noyer 2001. Movement Operations after Syntax, Linguistic Inquiry 32:4, 555-595.

Epstein, S. D. and Seely T.D. 1999. SPEC-ifying the GF "subject"; eliminating A-chains and the EPP within a derivational model. Ms., University of Michigan and Eastern Michigan State University.

Fanselow, G. 2002a. Quirky subjects and other specifiers, More Than Words, Ingrid Kaufmann, and Barbara Stiebels (eds.), Berlin: Akademie Verlag. 227-250.

Fanselow, G. 2002b. Munchausen-Style Head Movement and the Analysis of Verb Second, ms. 
Fassi-Fehri, Abdelkader. 1993. Issues in the structure of Arabic Clauses and Words, Studies in Natural language and Linguistic Theory 29, Kluwer Academic Publishers, Dordrecht.

Fave, V. 1998. Notennou yezadur, Emgleo Breiz: Brest.

Favereau, F. 1997. Grammaire du breton contemporain. Morlaix: Skol Vreizh.

Fleuriot, L. 1983. La loi de Bergin dans la Lingua Britannica, Brittonica, Etudes Celtiques $\mathrm{XX}: 101-118$.

Foley, 1991. The Yimas language of New Guinea, Stanford University Press.

Frey, W. 2006. Contrast and movement to the German prefield, Valeria Molnár \& Susanne Winkler (eds.), The Architecture of Focus, Studies in Generative Grammar 82, Berlin, New York:Mouton de Gruyter, 235-264.

Giannakidou, Anastasia. 1997. The landscape of Polarity Items, $\mathrm{PhD}$ ms, U. Gröningen.

Grohmann, K, J. Drury \& J. C. Castillo. 2000. No More EPP, WCCFL 19 Proceedings, Billerey and Lillehaugen (ed.), Somerville, MA: Cascadilla Press. 153-166.

Gro s, J. 1984. Le trésor du breton parlé III. Le style populaire. Brest: Emgleo Breiz - Brud Nevez.

Greenberg 1966. Some Universals of Grammar with Particular Reference to the Order of Meaningful Elements, in: Joseph H. Greenberg (ed.), Universals of Grammar, Cambridge (Mass.) - London, 1966, 73-113.

Haugan, J. 2000. Old Norse word order and information structure, Thesis ms.

Herrieu, L. 1994. Kammdro an ankoù, Al Liamm.

Hewitt, S. 1988. Ur framm ewid diskriva syntax ar verb brezoneg / Un cadre pour la description de la syntaxe verbale du breton, La Bretagne Linguistique, 4:203-11.

Hoekstra, T. \& R. Mulder. 1990. Unergatives as copular verbs; locational and existential predication, The Linguistic Review 7:1, 1-79.

Holmberg, A. 1997. Scandinavian Stylistic Fronting: phonological feature movement in the syntax, Working papers in Scaninavian Syntax 60, Department on Scandinavian Languages, University of Lund.

Holmberg, A. 2000. Scandinavian Stylistic Fronting: How any category can become an Expletive, Linguistic Inquiry 31:3, 445-483.

Holmberg, A. 2005. Stylistic Fronting, Martin Everaert and Henk van Riemsdijk (eds.) The Blackwell companion to syntax. Oxford: Blackwell, 2005, pp. 530-563.

Holmberg, A. and U. Nikanne, 2002. Expletives, Subjects and Topics in Finnish, Svenonius Peter (ed.), Subjects, Expletives and the EPP, Oxford University Press, 71-105.

Holmer, A. 2005. Seedicq, Antisymmetry and final particles in a Formosan VOS language, Verb-First, On the syntax of verb-initial languages, Carnie, Harley and Dooley (eds.), Benjamins Publishing Company, 175-202..

Huybregts, R. 1997. [talk on Nama syntax] "tindag, Linguistics in the Netherlands 28", January 18, 1997. University of Utrecht.

Huybregts, R. 2003. A PF interface condition on syntactic computation, J. Koster \& H van Riemsdijk (eds.); Germania and alia. A Linguistic Welbschrift for Hans den Besten.

Jouitteau, M. 2004. Gestures as Expletives, Multichannel Syntax of Spoken Languages, Proceedings of WCCFL 23, Cascadilla Press, 101-114.

Jouitteau, M. 2005a. Nominal Properties of $v$ Ps in Breton, a Hypothesis for the typology of VSO languages, VerbFirst: On the Syntax of Verb Initial Languages, Carnie, A. and Harley, H. (eds.), Amsterdam/Philadelphia: John Benjamins Publishing Company, 265280.

Jouitteau, M. 2005b/2010. La syntaxe comparée du Breton, une enquête sur la périphérie gauche de la phrase bretonne, Éditions Universitaires Européennes. (2005 PhD. ms.) 
Jouitteau, M. 2005c. Listen to the sound of salience, multichannel syntax, Romance languages and linguistic theory 2005, current issues in Linguistic Theory, Sergio Baauw et Frank Drijkoningen, John Benjamins Publishing Company, Amsterdam/Philadelphia, 185-200.

Jouitteau, M. 2007. The Brythonic Reconciliation, from verb-first to generalized verb-second, The Variation Yearbook 2007, J. Craenenbroek, Pica and J. Rooryck (eds.), Netherlands.

Jouitteau, M. 2011. Post-syntactic excorporation in realizational morphology: Evidence from Breton, Andrew Carnie (ed.), Formal Approaches to Celtic Linguistics, Cambridge Scholars Press. (extended version lingbuzz /001169).

Jouitteau, M. 2009-2018. ARBRES, site de recherche sur la syntaxe formelle de la microvariation syntaxique de la langue bretonne, http://arbres.iker.cnrs.fr.

Jouitteau, M. \& Rezac, M. 2006. Deriving the Complementarity Principle, Lingua 116:11, Special issue on Celtic Languages, 1915-1945.

Kandybowicz, J. 2008. The Grammar of Repetition, Nupe grammar at the syntax-phonology interface, John Benjamins Publishing Company.

Kato, M. 1999. Strong and Weak pronominals in the Null Subject Parameter, Probus 11:1-37.

Kim, J-H. 2004. El pro expletivo como una categoria vacia derivacional, Antonio Fabregas and Maria Elena Simoni (eds.), Cuadernos de Lingüistica XI, in memoriam Fernado Lazaro Carreter, 81-107.

Kim, S-W. 2003. The $\mathrm{X}^{\circ}$-EPP, a case of head-head dependency, Studies in Generative Grammar, vol. 13:2, 253-283.

Klima, Edward S. 1964. Negation in English, J.A. Fodor \& J.J. Katz (eds.), The structure of language. New Jersey: Prentice-Hall.

Koster, J. 2003. All languages are tense-second, Jan Koster and Henk van Riemsdijk (eds.), Germania et Alia: A Linguistic Webschrift for Hans den Besten.

Kučerová, I. 2005. The T-Extension condition, Procedings of the 24th West Coast Conference on Formal Linguistics, ed. John Alderete et al., 227-235. Somerville, MA: Cascadilla Proceedings Project.

Landau, I. 2007. EPP extensions, Linguistic Inquiry 38: 485-523.

Lasnik, H. 2001. A note on the EPP, Linguistic Inquiry 32.2.

Lasnik, H. 1999. Minimalist analysis. Oxford: Blackwell.

Lasnik, H. 1995. Case and Expletives revisited, Linguistic Inquiry 26, 615-633.

Lavine, James. 1998. Null Expletives and the EPP in Slavic: A Minimalist Analysis, S. Franks et al. (eds.), FASL VI: The Connecticut Meeting, Michigan Slavic Publications, Ann Arbor, pp. 212-230.

Lavine, J. and R. Freidin. 2001. The Subject of Defective T(ense) in Slavic, Journal of Slavic Linguistics. 10: 253-89.

Le Bozec, 1933. Le français par le breton, méthode bilingue, cours préparatoire, E. Thomas (ed.), Guingamp.

Lecarme, J. 1996. Tense in the Nominal System: the Somali DP, J. Lecarme, J. Lowenstamm and U. Shlonsky (eds), Studies in Afroasiatic Grammar, Selected papers from the Second Conference on Afroasiatic Languages, Sophia Antipolis 16-18 June 1994, pp. 159-178. The Hague: Holland Academic Graphics.

Leclerc, Louis. 1986, Grammaire Bretonne du dialecte de Tréguier, 3ième édition, Ar Skol Vrezhoneg, Emgleo Breiz, Brest. [first edition 1906, Prudhomme].

Le Gléau, R. 1973. Syntaxe du breton moderne: 1710-1972, Editions La Baule.

Maling, Joan 1980. Inversion in embedded clauses in Icelandic. 2, 175-193 [Reprinted 1990 in Modern Icelandic syntax, Joan Maling and Annie Zaenen (eds.), 71-91. San Diego: Academic Press]. 
Maling, Joan and A. Zaenen (eds.). 1990. Syntax and semantics 24: Modern Icelandic syntax, Academic Press, New York.

Martin, R. 1999. Case, the Extended Projection Principle, and Minimalism, Working Minimalism, S. Epstein \& N. Hornstein (ed.), Cambridge, Mass.: MIT Press.1-25.

Massam, D. 2005. "Predicate initial languages: What is a predicate?" On the Syntax of Verb Initial Languages, Carnie, A. and Harley, H. (eds.), Amsterdam/Philadelphia: John Benjamins Publishing Company.

Massam, D. 2010. V1 or V2?: On the left in Niuean, Jouitteau (ed.), Lingua 120: 284-302.

McCloskey, J. \& K, Hale. 1984. On the syntax of Person-Number Inflection in Modern Irish, Natural Language and Linguistic Theory 1, 487-533.

McCloskey, J. 1996. Subjects and subject positions in Irish, The Syntax of the Celtic Languages. Robert D. Borsley and Ian Roberts (eds.), Cambridge: Cambridge University Press. 241-283.

Miossec, Y. 1980, Dreist ar mor bras [= above the ocean], Brud Nevez 34-35, 66-72.

Miyagawa, S. 2003. A-movement scrambling and options without optionality, S. Karimi. (ed.), Word Order and Scrambling. Blackwell Publishers, 177-200.

Miyagawa, S. 2001. EPP, Scrambling, and Wh-in-situ," Ken Hale: A Life in Language. Michael Kenstowicz, ed., MIT Press, 293-338.

Moro, A. 1997. The raising of predicates. Cambridge: Cambridge University Press.

Ormazabal, J. 2002. The Inverse Case Filter, presentation at NELS 33.

Phillips, C. 1994. On the Nature of Polysynthetic Inflection, Proceedings of CONSOLE 2. Leiden: SOLE.

Platzack, C. 1998. A Visibility Condition for the C domain, Working Papers in Scandinavian Syntax, 61: 53-99.

Poletto, Cecilia. 2002. The left-periphery of V2-Rhaetoromance dialects: a new view on V2 and V3. Sjef Barbiers, Leonie Cornips \& Susanne van der Kleij (eds.), Syntactic Microvariation, 214-242. (Meertens Institute Electronic Publications in Linguistics 2). Amsterdam: Meertens Institute.

Rezac , M. 2004a. The EPP in Breton: An unvalued categorial feature, Triggers, Studies in Generative Grammar, A. Breitbarth \& H. v. Riemsdijk, Mouton de Gruyter.

Rezac, M. 2004b. Elements of cyclic syntax: Agree and Merge. PhD ms.

Rezac, M. 2011. 'Building and interpreting a nonthematic A-position: A-resumption in English and Breton', Alain Rouveret (éd.), Resumptive pronouns at the interfaces, Language faculty and beyond, Benjamins. 241-286.

Rivero, M.L. 1999. 'Stylistic verb-movement in yes-no Questions in Bulgarian and Breton', Crossing Boundaries, advances in the theory of Central and Eastern European languages, Kenesei, Istvan (éd.), Amsterdam, John Benjamins, 67-90.

Rizzi, L. 1990. Relativized Minimality, MIT Press, Cambridge, MA.

Rizzi, L. 1991, Proper Head Government and the Definition of A-positions, GLOW Newsletter 26:46-47.

Rizzi, L. 1997. The Fine Structure of the Left Periphery, Liliane Haegeman (ed.), Elements of Grammar: Handbook of Generative Syntax, Dordrecht: Kluwer, 281- 337.

Roberts, Ian. 1991. Excorporation and Minimality, Linguistic Inquiry, 22:1, 209-218.

Roberts, Ian and Anna Roussou 2002. The Extended Projection Principle as a condition on the tense dependency, Peter Svenonius (dir.) Subjects, expletives, and the EPP. Oxford: Oxford University Press, 125-155.

Roberts, Ian. 2005. Principles and Parameters in a VSO Language: A Case Study in Welsh, Oxford University Press. 
Rögnvaldsson, E. 1996. Word Order Variation in the VP in Old Icelandic, Working Papers in Scandinavian Syntax 58. 55-86.

Rögnvaldsson, E. and H. Thráinsson, 1990. On Icelandic Word Order Once More, J. Maling \& A. Zaenen (eds.) Syntax and semantics 24: Modern Icelandic syntax, 3-40, Academic Press, New York.

Rossello, J. 2000. A Minimalist Approach to the Null Subject Parameter, Catalan Working Papers in Linguistics, vol. 8, 97-128.

Rostrenen (de), G. 1795. Grammaire française-celtique ou française-bretonne, An III; nouvelle édition, Alain Le Fournier, Brest.

Sabel, J. 2000. Expletives as features. Proceedings of WCCFL 19, eds. R. Billerey et al., Somerville, MA: Cascadilla Press. 411-424.

Santorini, B. 1989. The Generalization of the Verb-Second Constraint in the History of Yiddish, $\mathrm{PhD}$ Dissertation, University of Pennsylvania.

Seite, V. 1988. O pourmen dre Vreiz-Izel, Levrenn genta. Emgleo Breiz.

Sheehan, M. 2006. The EPP and Null Subjects in Romance, Ph.D. dissertation.

Sigurosson, H. 1997. Stylistic Fronting, paper presented at the Second International Tromso Workshop on Linguistics, University of Tromso.

Sigurosson 2002. To be an oblique subject: Russian vs. Icelandic, Natural Language and Linguistic Theory, 20, 691-724.

Sigurosson, H. 2008. The case of PRO, Natural Language and Linguistic Theory 26:403-450.

Sigurosson, H. 2010. On EPP effects, Studia Linguistica 64:159-189.

Sifaki, E. 2003. EPP satisfiers: Verb-Initial Orders in Greek, ms. Thesis.

Skragn, J. M. 2002. Ma buhez e Kêr ar Vinaoued, Emgleo Breiz.

Stephens, J. 1982. Word order in Breton, Ph.D. thesis, School of Oriental and African Studies, University of London.

Storto, L. 2014. Information Structure and Constituent Order in Karitiana Clauses, Rik van Gijn, Jeremy Hannond, Dejan Matic, Saskia van Putten \& Ana Vilcay Galucio (eds.), Information Structure and Reference Tracking in Complex Sentences. Amsterdam/Philadelphia: John Benjamins Publishing Company. 163-191.

Stump, G. T. 1989. Further Remarks on Breton Agreement, Natural Language and Linguistics 7, 429-471.

Stump, G. T. 1984. Agreement versus Incorporation in Breton, Natural Language and Linguistics 2, 289-348.

Tomlin. 1984. The frequency of Basic Constituents Orders, Papers in linguistics 17, 163-196.

Toribio, A. J. 1996. Dialectal variation in the licensing of null referential and expletive subjects, C. Parodi, C. Quicoli, M. Saltarelli \& M. L. Zubizarreta (eds), Aspects of Romance linguistics. Washington, D.C.: Georgetown U. P., 409-432.

Travis, L. 1984. Parameters and Effects of Word Order Variation. ms. dissertation, MIT, Cambridge, MA.

Trépos, P. 2001 [1968, 1980, 1996], Grammaire bretonne, 1968 edition Simon, Rennes.1980 edition Ouest France, Rennes; 1996, 2001 édition Brud Nevez, Brest.

Trevidig, A. 1987. Dibarderioù rannyezh ar Poc'her, Hor Yezh 171-172.

Ura, Hiroyuki. 2000. Checking theory and grammatical functions in universal grammar. New York: Oxford University Press.

Vangsnes, Ø. 2002. Icelandic Expletive Constructions and the distribution of subject types, Peter Svenonius (ed.): Subjects, Expletives and the Extended Projection Principle, Oxford University Press, 43-70.

Wali, Kashi and Koul, Omkar N. 1997. Kashmiri: A Cognitive-descriptive Grammar, Londres : Routledge. 
Willis, D. 1998. Syntactic Change in Welsh, A study of the loss of verb-second, Clarendon Press, Oxford.

Zubizarreta, M.-L. 1998. Prosody, Focus and Word-order. Cambridge, Mass: MIT Press.

Zwart, I. W. 1993. Dutch syntax: a minimalist approach. Dissertation Rijksuniversiteit Gröningen. 